\title{
Scientists prefer them blind: the history of hypogean fish research
}

\author{
Aldemaro Romero \\ Environmental Studies Program and Department of Biology, Macalester College, 1600 Grand Ave., St. Paul, \\ MN 55105-1899, U.S.A. (e-mail: romero@macalester.edu)
}

Received 22 December $2000 \quad$ Accepted 24 January 2001

Key words: neo-Lamarckism, orthogenesis, typological thinking, neo-Darwinism, evolution, evolutionary progress, regressive evolution

\section{Synopsis}

The history of hypogean fish research has been strongly influenced by neo-Lamarckism (including orthogenesis) and typological thinking. Only in the last few decades neo-Darwinism has made any inroads in the research approach to this subject. The majority of the most distinguished and productive hypogean fish researchers have used their research subjects to confirm their own views on evolution rather than to use those subjects as a spring of knowledge to enrich mainstream biological thought. Of these views, I found that the most perversive of all is the notion of evolutionary 'progress' that has led many researchers to envision hypogean fishes as prime examples of 'regressive' evolution. I propose that the utilization of hypogean fishes for the study of convergent evolution should catapult these subjects of research into prime objects of evolutionary ideas.

\section{Introduction}

The development of a particular area of science is deeply influenced by its history. Through historical studies, one can better perceive the impacts of fashion, error, and the effects of conceptual inertia (Horder 1998). By doing that the researcher can also project the best venues to develop future lines of research.

In this paper I analyze the scientific views on the nature of hypogean fishes. I will contend that both neoLamarckism (including orthogenesis) and typological thinking have prevented the use of hypogean fishes as one of the prime examples to explain some general biological phenomena in evolutionary biology as it is the case for convergent evolution. Another question is how hypogean fish research fits within the broader context of the history of three sub-disciplines: ichthyology, speleology, and evolutionary biology. This is a rather difficult task due to lack of current contextual material.

For example, a comprehensive history of ichthyology has yet to be written. Although some attempts have been made, none of these give us the entire picture.
They are either too old (Cuvier 1828 [1995], Günther 1880 , Jordan 1905) or limited in scope geographically (Myers 1964, Hubbs 1964) or conceptually (Pietsch \& Anderson 1997). Thus, there is not an appropriate background to refer to in this regard. The history of speleology has faced similar problems. The only attempt to summarize the history of this field emphasized geomorphology (Shaw 1992). Barr's (1966) short article on the history of cave research is confined to the United States. The role played by the study of cave organisms in general on the neo-Lamarckian movement in the United States as well as the idea of progress is better known (e.g., Ruse 1996).

\section{Methods}

I compiled 1607 published references on hypogean fishes. They were obtained by using standard bibliographical sources, including the Zoological Record up to 1999 , the Biological Abstracts up to June 2000, Dean's Bibliography of Fishes (Dean 1916-1923), 
Current References in Fish Research (Cvancara ${ }^{\mathrm{l}}$ ), as well as other bibliographical data that I have accumulated in the last 20 years. These references were analyzed by author, topic, year of publication, and by country/institution using ProCite $5{ }^{2}$ I emphasized studies on hypogean fishes that show some degree of troglomorphy (blindness, depigmentation) The study of non-troglomorphic hypogean fishes, despite their tremendous potential for understanding the processes of cave colonization and evolution, has been largely overlooked by scientists and, thus, have remained mostly anecdotal (Poly 2001). Although this type of compilation can never be fully complete, I am confident that I have studied and analyzed all relevant sources.

In order to provide adequate historical and geographical context, I have added the dates and places of birth and death in parentheses after mentioning, for the first time, all major players in the history of hypogean fish research. Secondary players are only given the years of birth and death, when known. All scientific names of fishes are given following Romero (2001a). I used this instead of Eschmeyer's standard Catalogue of Fishes ${ }^{3}$ because that list is sometimes ambiguous when it comes to specific names for certain hypogean populations and it is not entirely complete regarding hypogean species. Sometimes those names are followed by parentheses to mention the name with which the species was originally described. For referential purposes, I present the chronology of the discovery of valid species/populations of troglomorphic fishes in Table 1.

\section{Results}

I identified six periods of hypogean fish research: (1) pre-Linnean (1541-1752), (2) first discoveries and research (1805-1864), (3) American neo-Lamarckism (1868-1919), (4) dominance of typological thinking (1921-1940), (5) American renaissance (1936-1960), and (6) times of philosophical conflict (1960-1990). Notice that between (1), (2), (3), and (4) there are gaps; this is because during those in-between years nothing significant happened in the field. On the other hand, there is an overlap between (5) and (6); this is because the American and European schools that dominated

\footnotetext{
${ }^{1}$ Cvancara, V.A. 1976-1998. Current references in fish research, 23 volumes.

${ }^{2} 2000$. ProCite Version 5.0. ISI ResearchSoft, Berkeley.

${ }^{3}$ http://www.calacademy.org/research/ichthyology/catalog/
}

Table 1. Chronological order of discoveries of troglomorphic species/populations of hypogean fishes (sensu Romero 2001a). Following an asterisk is the author that reported the first hypogean/troglomorphic population of an already described epigean species.

Amblyopsis spelaea DeKay, 1842

Lucifuga (Lucifuga) subterraneus Poey, 1858

Lucifuga (Stygicola) dentatus Poey, 1858

Typhlichthys subterraneus Girard, 1859

Chologaster agassizii Putnam, 1872

Amblyopsis rosae (Eigenmann, 1897)

Phreatobius cisternarum Goeldi, 1905

Pimelodella kronei (Miranda-Ribeiro, 1907)

Trogloglanis pattersoni Eigenmann, 1919

Caecobarbus geertsii Boulenger, 1921

Uegitglanis zammaranoi Gianferrari, 1923

Phreatichthys andruzzii Vinciguerra, 1924

Rhamdia quelen (Quoy \& Gaimard, 1824) (*Norman 1926)

Barbopsis devecchii Di Caporiacco, 1926

Typhleotris madagascariensis Petit, 1933

Clarias cavernicola Trewavas, 1936

Astyanax fasciatus (Cuvier, 1819) ("Hubbs \& Innes 1936)

Ogilbia pearsei (Hubbs, 1938)

Ophisternon infernale (Hubbs, 1938)

Luciogobius pallidus Regan, 1940

Luciogobius albus Regan, 1940

Iranocypris typhlops Bruun \& Kaiser, 1944

Milyeringa veritas Whitley, 1945

Satan eurystomus Hubbs \& Bailey, 1947

Trichomycterus conradi (Eigenmann, 1912) (*Schultz 1949)

Horaglanis krishnai Menon, 1950

Prietella phreatophila Carranza, 1954

Typhlogarra widdowsoni Trewavas, 1955

Garra barreimiae barreimiae Fowler \& Steinitz, 1956

Typhleotris pauliani Arnoult, 1959

Ophisternon candidum (Mees, 1962)

Astroblepus pholeter Collette, 1962

Poecilia mexicana Steindachner, 1863 (*Gordon \& Rosen 1962)

Ogilbia galapagosensis (Poll \& LeLeup, 1965)

Stygichthys typhlops Brittan \& Böhlke, 1965

Trichomycterus chaberti Durand, 1968

Nemacheilus evezardi Day, 1872 (*Thines 1969?)

Lucifuga (Stygicola) spelaeotes Cohen \& Robins, 1970

Speoplatyrhinus poulsoni Cooper \& Kuehne, 1974

Paracobitis smithi (Greenwood, 1976)

Pterocryptis cucphuongensis (Mai, 1978)

Triplophysa gejiuensis (Chu \& Chen, 1979)

Caecocypris basimi Banister \& Bunni, 1980

Oreonectes anophthalmus Zheng, 1981

Lucifuga (Stygicola) simile Nalbant, 1981

Rhamdia laticauda (Kner, 1858) (*Greenfield et al. 1982)

Typhlobarbus nudiventris Chu \& Chen, 1982

Nemacheilus starostini Parin, 1983

Rhamdia redelli Miller, 1984

Triplophysa xiangxiensis (Yang, Yuan \& Liao, 1986)

Sinocyclocheilus anatirostris Lin \& Luo, 1986

Garra dunsirei Banister, 1987 
Table 1. Continued

Nemacheilus sijuensis Menon, 1987

Ancistrus cryptophthalmus Reis, 1987

Sinocyclocheilus anophthalmus Chen, Chu, Luo \& Wu, 1988

Sinocyclocheilus cyphotergous (Dai, 1988)

Schistura oedipus (Kottelat, 1988)

Cryptotora thamicola (Kottelat, 1998)

Lucifuga (Lucifuga) teresinarum Díaz Perez, 1988

Sinocyclocheilus microphthalmus Li, 1989

Nemacheilus troglocataractus Kottelat \& Géry, 1989

Sinocyclocheilus angularis Zheng \& Wang, 1990

Triplophysa yunnanensis Yang in Wu, 1990

Schistura jarutanini Kottelat, 1990

Sundoreonectes tiomanensis Kottelat, 1990

Monopterus eapeni Talwar in Talwar \& Jhingran, 1991

Poropuntius speleops (Roberts, 1991)

Caecogobius cryptophthalmus Berti \& Ercolini, 1991

Triplophysa shilinensis Chen \& Yang, 1992

Rhamdia zongolicensis Wilkens, 1993

Glossogobius ankaranensis Banister, 1994

Sinocyclocheilus hyalinus Chen \& Yang in Chen, Yang \& Zhu, 1994

Protocobitis typhlops Yang, Chen \& Lan, 1994

Ancistrus galani Perez \& Viloria, 1994

Astroblepus riberae Cardona \& Guerao, 1994

Prietella lundbergi Walsh \& Gilbert, 1995

Oxyeleotris caeca Allen, 1996

Eigenmannia vicentespelaea Triques, 1996

Trichomycterus itacarambiensis Trajano \& de Pinna, 1996

Ancistrus formoso Sabino \& Trajano, 1997

Sinocyclocheilus furcodorsalis Chen, Yang \& Lan, 1997

Paracobitis longibarbatus Chen, Yang, Sket \& Aljancic, 1998

Monopterus roseni Bailey \& Gans, 1998

Rhamdia macuspanensis Weber \& Wilkens, 1998

Pterocryptis buccata $\mathrm{Ng}$ \& Kottelat, 1998

Troglocychlocheilus khammouanensis Kottelat \& Brehier, 1999

each of those periods, respectively, were very much independent of each other, not only geographically but also conceptually (see below).

\section{Pre-Linnean times (1541-1752)}

The first known printed reference of a hypogean fish is that of the hyaline fish, Sinocyclocheilus hyalinus; reported by $\mathrm{Jie}^{4}$ (1541) for the Alu Limestone caves $\left(103^{\circ} 45^{\prime} \mathrm{E}, 24^{\circ} 33^{\prime} \mathrm{N}\right)$ in what is today Luxi County, Yunnan, China. However, specimens of the hyaline fish were not collected for research until 1991 and the description of the species was not published in the

\footnotetext{
${ }^{4}$ Jie, Yi-Jing. 1541. Report on the Alu Cave. Publisher's name and place of publication unknown (in Chinese).
}

scientific literature until three years later (Chen et al. 1994).

There are at least three more pre-Linnean printed references to hypogean fishes, all of them from Europe. Given that they have been cited as precursors in the history of biospeleology, it is important to analyze their validity as true scientific developments.

The first was by Jacques Besson (b. Colombières, France, 1530?; d. Orléans, France, 1573). He was an engineer and mathematician with no formal training in the natural sciences (Romero \& Lomax 2000). Besson (1569, p. 41) reported little eels ('petites anguilles') in a cave stream. Although Shaw (1992, p. 227) claims that such observation took place 'in a cave stream in France', Besson did not give a locality of where he made that observation. Besson did not describe the fish as being blind and/or depigmented (extraordinary characteristics even to the casual observer). He may have seen common eels, Anguilla anguilla, or a species of some of the European freshwater fishes with eel-like bodies that are sympatric with the areas he used to travel (France and Switzerland). Those fish families include Petromizontidae, Cobitidae, Siluridae, and Clariidae (Blanc et al. 1971).

The second was Athanasius Kircher (b. Geisa, Germany, 2 May 1602; d. Rome, 28 November 1680). This prolific Jesuit priest polymath wrote, in what is probably the first printed work on speleology (Figure 1), that "There is also in the landscape of Krain [Carniola?] close to the town Haubach a huge field from which each year during Spring time a large body of water containing fish bursts forth with the result that in a few days it transforms the field into a lake teeming with fish (...) in Switzerland rivers rise from the caves of the mountains, that flow from May until September, but stop the rest of the time (...) as they come out of the mountains, are full of fish, which is clear proof that they [the fish] emerge from subterranean waters along the rivers $(. .$.$) it is not implausible that, as under the$ earth all kind of fishes occur and live' (Kircher 1665, 2, p. 85). These references to subterranean fishes, however, are vague, unsubstantiated, and given Kircher's reputation as an uncritical repeater of other people's tales, highly suspect (Romero 2000). Furthermore, he makes no reference to features associated with troglomorphic fishes - blindness and depigmentation.

The third pre-Linnean reference to subterranean fishes in Europe was by Marc-René Marquis de Montalembert (b. Angoulême, France, 16 July 1714; d. Paris, France, 29 March 1800) (Figure 2). He was 


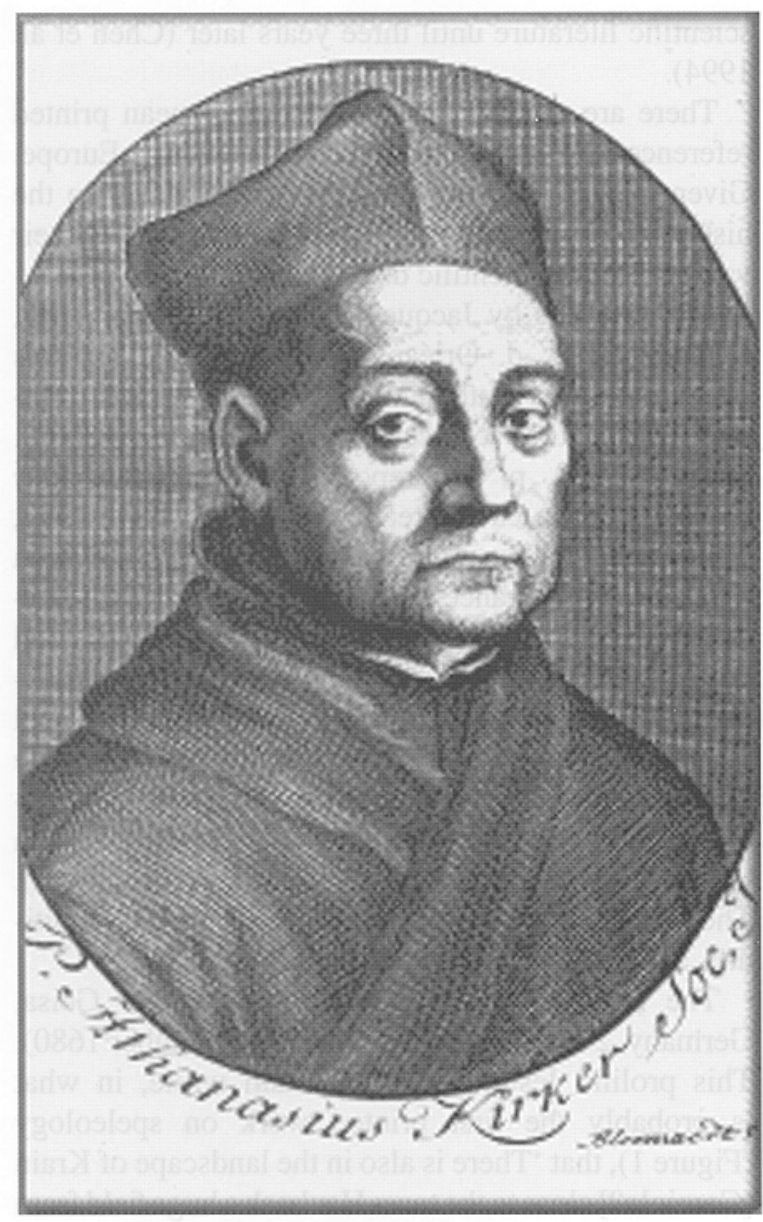

Figure 1. Athanasius Kircher.

an aristocrat, military man, and engineer known for his design of fortifications. He reported a blind, subterranean fish in a spring at Gabard, Angoumois, near one of his estates in southwestern France. He noted: 'it is common to fish either blind or one-eyed pike; one-eyed ones always miss the right eye and among the blind ones, the right eye seems further reduced than the left eyes' (Montalembert 1748, p. 28). He left no drawings, much less preserved specimens. He said that what he saw was a pike. That, by itself, is not surprising. The pike, Esox lucius, is by far the most common freshwater fish of the Northern Hemisphere. The fact that this fish can be identified as a pike despite being blind is also not surprising. Many hypogean fishes are almost identical to their surface, epigean forms except for the reduction of eyes and pigmentation. But Montalembert never mentioned depigmentation in his description. Furthermore, he says that

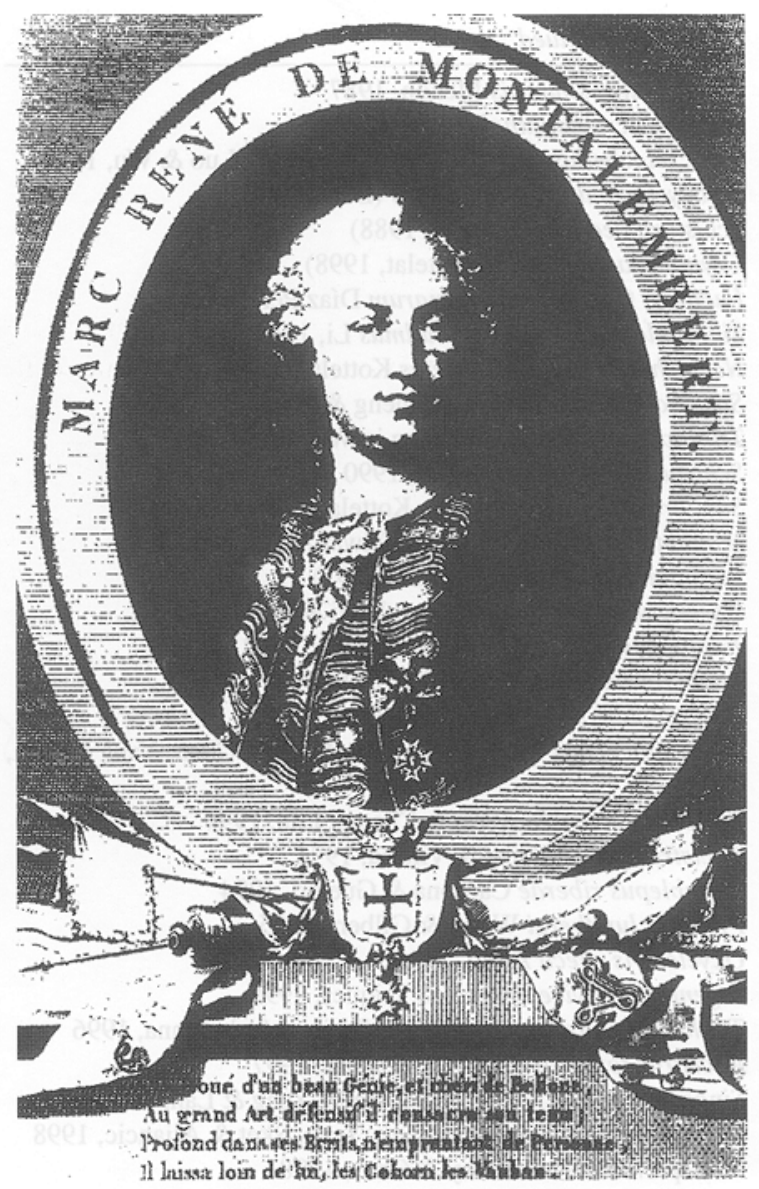

Figure 2. The only known portrait of Marc René de Montalembert.

some of the fish lacked one eye and, when that was the case, it was always the right eye. Troglomorphic fish generally show the same degree of reduction in both eyes. Finally, the location mentioned by Montalembert cannot be found today (Romero 1999a) nor has any true blind cave fish ever been described from Europe.

Thus, all pre-Linnean reports of European troglomorphic hypogean fishes are unsupported by scientific evidence. Two of them (Besson's 1569, Kircher's 1665) do not even describe them with the typical troglomorphic features while the third (Montalembert 1748) is suspect. The most compelling evidence that the reports by these three authors are inaccurate is the fact that no true troglomorphic fish has been found in Europe to this date. All the European citations display the characteristic of their times: vague (Besson's), uncritical and scholastic (Kircher's), or fascinated with monstrosities 
(Montalembert). Among all pre-Linnean references, only Jie's (1541) has been substantiated by facts.

\section{First discoveries and research (1805-1864)}

This period was characterized by two factors: The first is the discovery and publication in the scientific literature of the first species of troglomorphic fishes. The second is the use of morphological studies aimed to describe in detail their different features. During this period all troglomorphic fishes were found either in the United States or Cuba. In the United States, the years preceding the American Civil War (1861-1865) were marked by explorations by both individuals acting independently and state-sponsored surveys.

An early published post-Linnean record of a possible hypogean fish is that of Alexander von Humboldt (1769-1859) who described Astroblepus cyclopus (= Pimelodus cyclopum) which, according to him, could be found in the subterranean waters in the Andes of Quito in the basin of Río Esmeraldas, Ecuador (Humboldt 1805). However, he never saw that fish in any hypogean environment (Romero \& Paulson 2001). Furthermore, this is actually an eyed, pigmented species with ample distribution in northwestern South America (Burgess 1989, p. 448).

The first published record of a confirmed troglomorphic fish in the Western Hemisphere is probably that of James Flint. He was a Scotchman who, while visiting the United States, lived for several months in Jeffersonville, Indiana, in 1820 and recorded that 'a Colonel C - [sic] of Indiana told me that a settler in his neighbourhood [sic] digging a well, penetrated into a stream of water, and found blind fishes in it.' He added as a footnote that 'Since the above was written, a notice of blind fishes has appeared (if I mistake not) [sic] in the memoirs of the Wernerian Society of Edinburgh' (Flint 1822, p. 256). I reviewed the entire collection of this journal, which consists of eight volumes published between 1808 and 1838, and did not find any reference to that blind fish.

The first published report of a troglomorphic fish sighted in its natural environment in the Western Hemisphere was, probably, by Robert Davidson (1808-1876). In October 1836 he visited Mammoth Cave in Kentucky accompanied by Stephen Bishop (1780-1850), a self-educated black slave who guided visitors through the cave. He reported that "white fish were found here without eyes' whose existence was

\footnotetext{
${ }^{5}$ Italics in the original.
}

already known by some of the locals (Davidson 1840 , pp. 54-56). Others have pointed out that it was on 20 September 1838 that the Echo River in Mammoth Cave was discovered, and in it, a blind fish (Soule 1982).

The first time that a troglomorphic fish was mentioned in the scientific literature was in a short note in the Proceedings of the Academy of Natural Sciences of Philadelphia (Anonymous 1842). There it was reported that a W.T. Craigie donated to the Academy at the 24 May 1842 meeting a specimen of 'a small white fish, also eyeless (presumed to belong to a subgenus of Silurus), taken from a small stream called the "River Styx" in the Mammoth Cave, Kentucky, about two and one-half miles from the entrance'. Today, at the collection of the Academy there are three specimens of Amblyopsis spelaea in alcohol, that appear linked to this donation. Two are catalogued as ANSP 7964 collected by W.T. Craige, and the other, ANSP 7964, collected by 'Mrs. C.H. Graff, Messrs. Craige \& Lambert'. All three specimens were captured in Mammoth Cave, but no dates are given.

The first scientific description of a troglomorphic fish was carried out by James Ellsworth DeKay (b. Lisbon, Portugal,.12 October 1792; d. Oyster Bay, Long Island, New York, 21 November 1851) (Figure 3). Son of an American captain stationed in Lisbon, DeKay studied medicine at Yale and Edinburgh, Scotland. He was one of the founders of the Academy of Medicine and an active member of both the New York Lyceum of Natural History and the American Association for the Advancement of Science. He was the first of the first-generation of American-born naturalists making important contributions in ichthyology (Hubbs 1964).

DeKay's work can be framed within the movement that started in the 1940's when several states of the United States inaugurated natural history surveys and published catalogues of the local faunas (Coe 1918). He was selected to contribute a book on the zoology of New York state. In it, DeKay (1842, pp. 187-188) gave the first recognized scientific description of a troglomorphic fish, the northern cavefish, Amblyopsis spelaea (= Amblyopsis spelaeus). The description was not very detailed nor of a great quality. This could have been due to the fact that it was based on a poor specimen in the Cabinet of the Lyceum of Natural History of New York (Putnam 1872) or to the fact that DeKay was not a trained ichthyologist (Smallwood 1941, pp. 163-164).

Although the northern cavefish was captured in the River Styx, Mammoth Cave, Kentucky, DeKay included that and many other non-New York species 


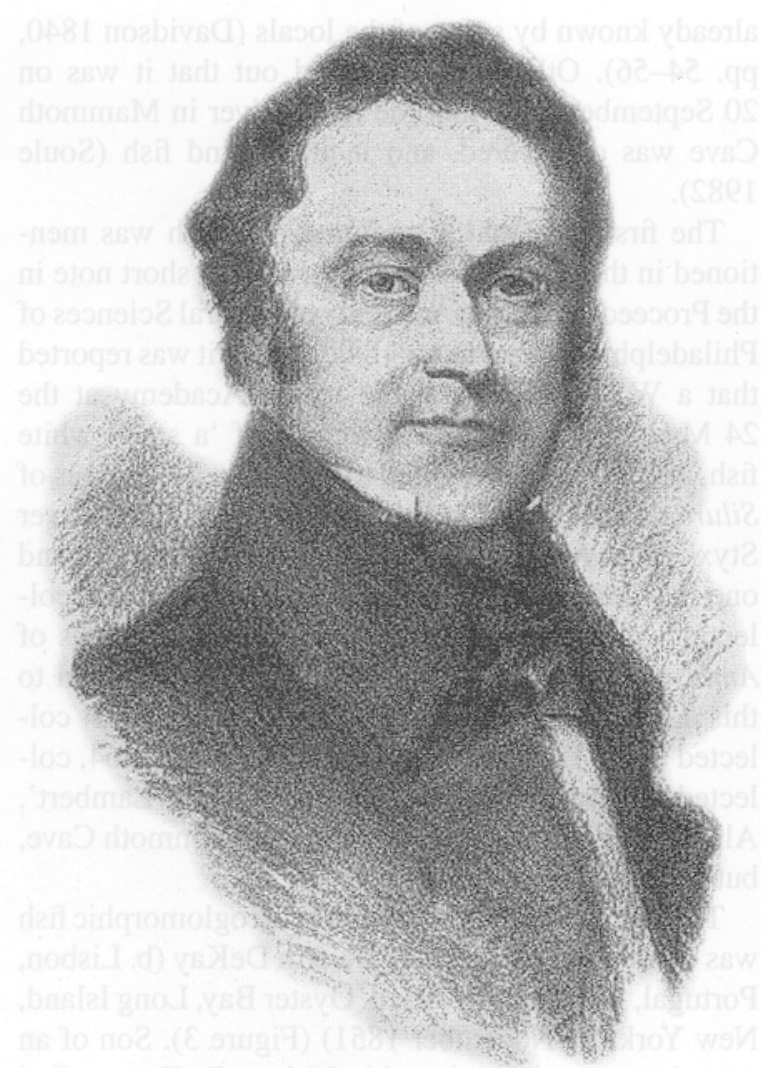

Figure 3. James Ellsworth DeKay, the first who described in the scientific literature a troglomorphic fish, Amblyopsis spelaea.

because 'It cannot therefore fail to be perceived that the Ichthyology of New-York will embrace a very large proportion of the Fishes of the United States' (DeKay 1842 , p. iv). He actually placed this new species in a list of fishes under the subheading '(EXTRA-LIMITAL)' [sic]. The specimen, which originally belonged to the Cabinet of the Lyceum of Natural History of New York, cannot be located today and is presumed lost.

DeKay would never write about Amblyopsis again; however, this fish caught the attention of a number of anatomists who immediately began to study it. The first of those was Jeffries Wyman (b. Chelmsford, Middlesex, Massachusetts, 11 August 1814; d. Bethlehem, New Hampshire, 4 September 1874) (Figure 4). He graduated in medicine from Harvard University in 1837 and studied under George Cuvier and Richard Owen (Gifford 1967). Wyman helped to lay the foundations of comparative anatomy in the U.S. He was responsible - together with Louis Agassiz and Asa Gray - for making Harvard the most important center for the study of natural history in the

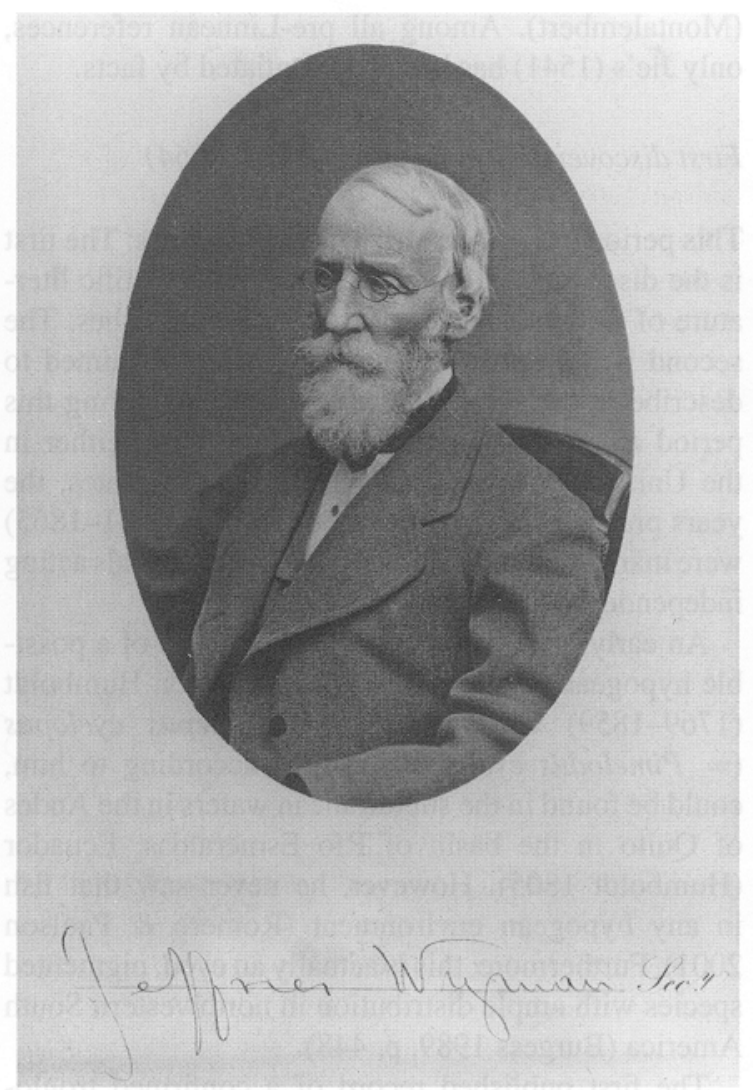

Figure 4. Jeffries Wyman (courtesy of the Ernst Mayr Library of the Museum of Comparative Zoology, Harvard University (c) President and Fellows of Harvard College).

United States. He is little remembered today mostly because he was a very modest man who avoided generalizations.

Wyman, Agassiz, and Gray, embraced the philosophical, or transcendental anatomy, i.e., the search for ideal patterns of structure in nature (Appel 1988). Thus, the discovery of a blind cave fish attracted Wyman's attention and he described A. spelaea in great detail (Wyman 1843), to the point that some have mistakenly referred to him as the first person who described a blind cave fish (e.g., Gurnee 1992).

In his first paper on A. spelaea, he reported that 'On the most careful dissection no traces of eyes were found' (Wyman 1843, p. 96). Later he wrote that 'The optic lobes existed; according to the general rules of physiology these should not exist; as they bare strict relation to the sense of sight, which receives its nerve from them (...) Here the optic lobes were not so large as the allies fishes, but yet they were of good size, and 
nearly as large as the cerebral lobes' (Wyman 1851, p. 349). He later re-examined three specimens and found imperfect eyes covered by tissue and, hence, unable to see. He proposed that this imperfection of the eyes 'might be owing to a want of stimulus through a series of generations' and that the organ of vision, however imperfect, 'it is more like the eyes of other vertebrates' (Wyman 1854a, p. 19). He also pointed out numerous structures without evident functions, organs that were of morphological rather than physiological value (Wyman 1854b). He produced very detailed drawings of the internal anatomy of A. spelaea (Wyman 1872).

For Wyman, A. spelaea was an excellent subject of study in his quest for evidence of a common plan underlying the differences caused by adaptive modifications. Although he quickly converted to evolutionism, he did not accept natural selection as its mechanism. He even regarded Agassiz as backwards for his refusal to accept evolution (Appel 1988). Yet, all of his papers on A. spelaea were devoid of evolutionary speculations, something that characterized most of his writings.

The next naturalist to study A. spelaea was August Otto Theodor Tellkampf (b. Heinde, Germany, 27 April 1812; d. Hannover, Germany, 7 September 1883) (Romero 2001b). He 'Americanized' his name by adding either 'A.'or 'G.' as his middle initial. In 1838 he received a doctorate in Medicine from the University of Wurzburg, Bavaria, and immigrated into the United States in 1839, where he practiced medicine in Cleveland and New York. He had some interests in cave fauna, having visited Mammoth Cave in October 1842 (Tellkampf 1844a,b), and described several species of invertebrates. He was a member of the Lyceum of Natural History of New York.

Tellkampf contributed detailed descriptions of A. spelaea and concluded that its eyes and those of blind cave crayfishes had become rudimentary as a result of disuse: 'While it is true, in general, that all animals retain their essential form, and that no species passes over into another by transformation, we know that less material changes of form are produced by external influences such as changes in climate or food, lasting though many generations of the same species'. But if the lack of light could only produce change within a species, then where was the original unmodified species? Tellkampf remained cautious on this point: the relationship of the blind fauna to unmodified species could not be settled until 'such species, corresponding with them in all essential points, are found' (Tellkampf 1844b, p. 393).
European-based researchers also started to show interest in A. spelaea. By January 1844 a specimen had arrived in Edinburgh, Scotland, that was collected by townsman Gordon A. Thompson. William Thompson (1805-1852), then president of the Belfast Natural History and Philosophical Society, reported it as 'perhaps the first examples of their respective species brought thence to Europe' (Thompson 1844, p. 111).

Thus, during the first years of research into A. spelaea, this fish was considered to be largely a curiosity with varying significance. It was not until 1847 that the first published insight on the potential importance of troglomorphic fishes to biological research was published. Interestingly enough, it came from an unrepentant anti-evolutionist: Jean Louis Rodolphe Agassiz (b. Motieren-Vuly, Switzerland, 28 May 1807; d. Cambridge, Massachusetts, 14 December 1873) (Figure 5). During the 5 October 1847 meeting of the American Academy of Arts and Sciences, Agassiz

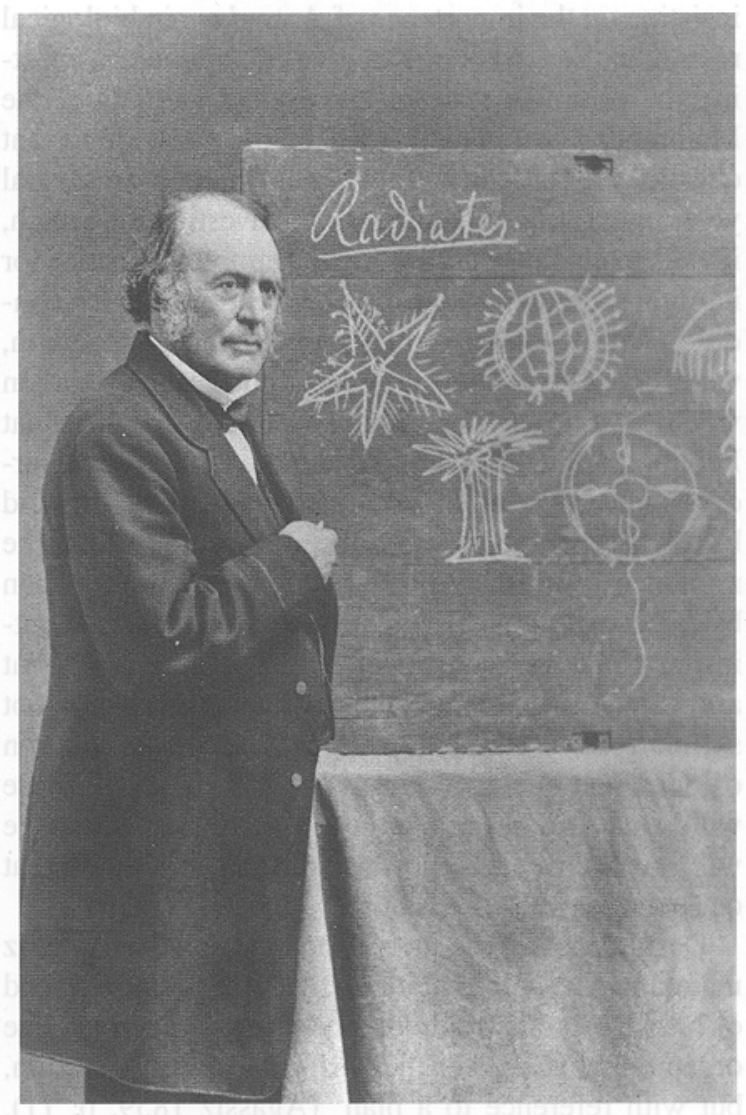

Figure 5. Louis Agassiz (Courtesy of the Ernst Mayr Library of the Museum of Comparative Zoology, Harvard University (c) President and Fellows of Harvard College). 
proposed a 'Plan for an investigation of the embryology, anatomy and effect of light on the blind-fish of the Mammoth Cave, Amblyopsis spelaeus' (Agassiz 1847, p. 180). There he suggested that by studying this fish 'there was an opportunity to settle, by actual experiment, the extent of physical influences in causing organized beings to assume their peculiar and distinctive characteristics in relation to the media in which they live'. Agassiz, the creationist, was not thinking in terms of the environment influencing evolution, but rather the effects of the environment on development. He proposed to raise individuals of $A$. spelaea under different light conditions (darkness, moderate, and intense light) and see if 'there is an eye formed in the dark to ascertain when and how (the pigmentation) disappears, as it is entirely wanting in the full-grown individuals, and again notice the differences in this respect between specimens growing under the influence of light' (Agassiz op. cit., p. 180).

He never carried out those experiments, yet he kept insisting on the importance of $A$. spelaea in biological research: 'You asked me to give my opinion, respecting the primitive state of the eyeless animals of the Mammoth Cave. This is one of the most important questions to settle in natural history, and I have several years ago, proposed a plan for its investigation which, if well conducted would lead to as important results, for it might settle, once for ever, the question, in what condition and where the animals now living on the earth, were first called into existence. But the investigation would involve such long and laborious researches, that I doubt it will ever be undertaken. (...) If physical circumstances ever modified organized beings, it should be easily ascertained here.' Dèspite these difficulties he remained optimist: 'Whoever would settle the question by direct experiment might be sure to earn the everlasting gratitude of men of science, and here is a great aim for the young American naturalist who would not shrink from the idea of devoting his life to the solution of one great question' (Agassiz 1851, p. 255). These words may not have fallen into a vacuum since, as we will see below, several of his students showed a great deal of interest in cave fishes.

Despite his insight, there is no question that Agassiz maintained an anti-evolutionist view until the very end of his life. On the rudimentary organs, he wrote 'The organ remains, not for the performance of a function, but with reference to a plan' (Agassiz 1859, p. 11). He considered A. spelaea to be an 'aberrant cyprinodont (...) created under the circumstances in which they now live' (Agassiz 1851, p. 256). And he never changed his mind: 'Have fishes descended from a primitive type? So far am I from thinking this possible, that I do not believe there is a single specimen of fossil or living fish, whether marine or fresh-water, that has not been created with reference to a special intention and a definite aim' (Agassiz 1885, 1, pp. 392-393).

The next scientist who would make significant contributions to the study of hypogean fishes was Felipe Poey (b. La Habana, Cuba, 26 May 1799; d. La Habana, 28 January 1891). He was a lawyer in Cuba, where tales of troglomorphic fishes were around since at least 1831. Poey secured the specimens and described two new species: Lucifuga subterraneus and Lucifuga dentatus ( $=$ Stygicola dentatus) $($ Poey 1858, 2, p. 100) (Figure 6). The descriptions of these two species were extraordinary on several accounts. Not only were they very detailed and precise from the external and internal anatomical viewpoints, but there was also a wealth of information on their behavior, habitat and history. Further, based on specimens he received from the United States, he described A. spelaea, for comparative purposes. The descriptions of the Cuban species were far superior to those published on $A$. spelaea by his American and European counterparts. Poey also demonstrated full familiarity with the published literature on cave fishes up to that time.

It would be easy to label Poey as an 'isolated genius' (sensu Beddall 1983) from social, scientific, and geographic viewpoints. He lived in a country which, at that time, was still a colony of Spain and lacked strong academic institutions. Poey himself was the founder of the first Cuban natural history museum and the first who taught zoology at the University of Havana. Yet he was not isolated from the scientific community. Poey was in contact with the most prominent contemporary researchers of cave fishes including Girard, Gill, Packard, and Putnam (see below). The latter visited Poey in Cuba in 1886 (Cockerell 1920). He received specimens of $A$. spelaea which he examined for his comparative studies adding information and making corrections to previous observations (Poey 1858, 2, pp. 104-106). He also provided American institutions such as the Museum of Comparative Zoology with specimens of the Cuban hypogean fish (Putnam 1872).

The next species was described by Charles Frédéric Girard (b. Mulhouse, France, 8 March 1822; d. Neulilly-sur-Seine, France, 29 March 1895). He had been brought to the United States by Louis Agassiz in 1847 and later worked at the Smithsonian Institution until 1860 . While there, he was given some specimens 


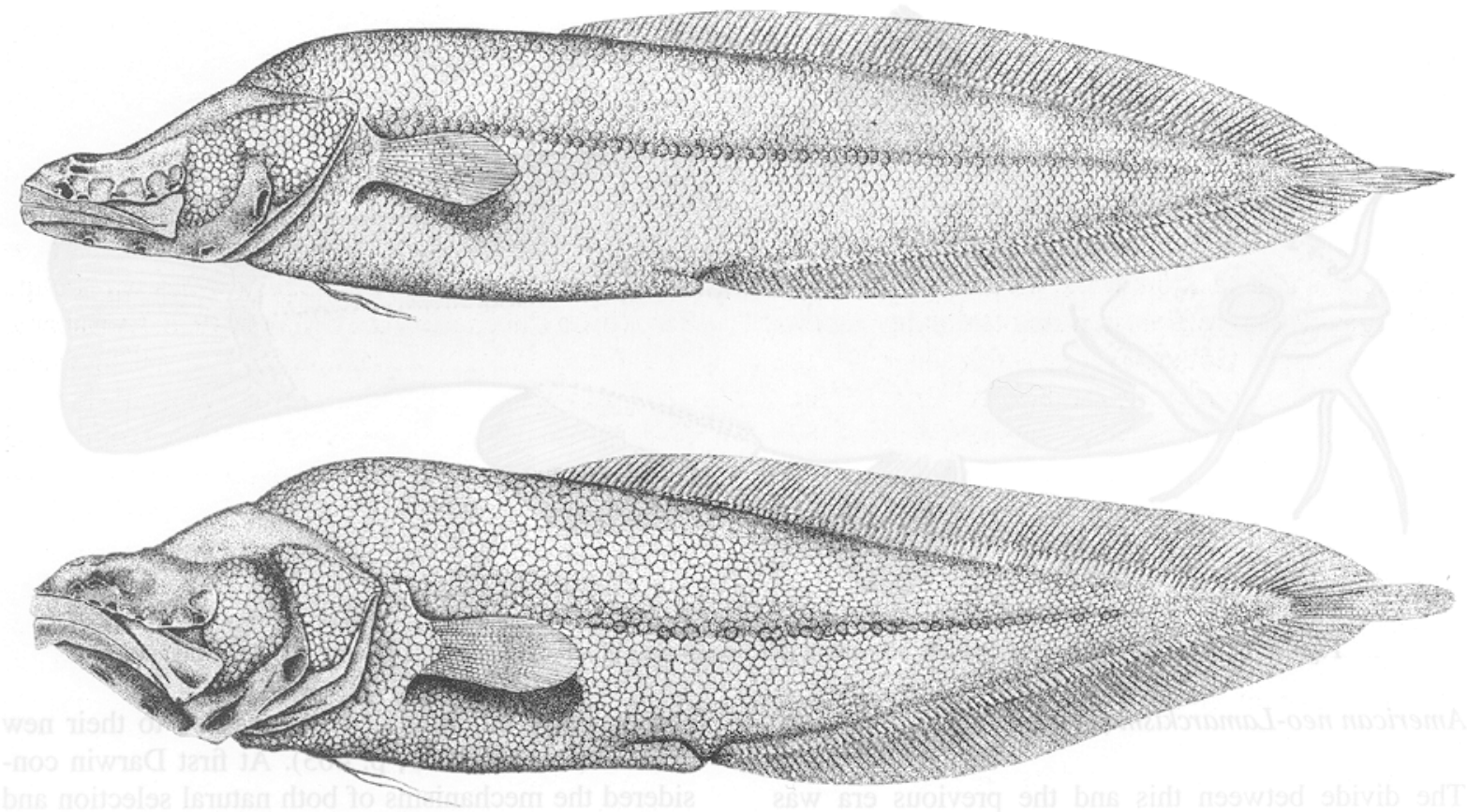

Figure 6. A 1902 illustration of Lucifuga subterraneus (top) and Lucifuga dentatus by C.H. Kennedy (courtesy of the Smithsonian Institution, NMNH, Division of Fishes).

collected by a J. E. Younglove 'from a well near Bowling Green, Ky'. He gave those specimens a new species status, Typhlichthys subterraneus, which he included in the family Amblyopsidae (Girard 1859). This new species seemed to have "characters apparently transitory' between A. spelaea and the other species of the amblyopsid family known at that time: Chologaster cornutus, an epigean species. A. spelaea lacked eyes but had ventral fins; $T$. subterraneus lacked both eyes and ventral fins, while $C$. cornuta had eyes and lacked ventral fins.

The Civil War broke out while Girard was in Paris where he stayed and supported the Confederate cause by sending drugs, medical supplies, and arms. After the war he stayed in France where he practiced medicine (Jackson \& Kimler 1999). Apparently he maintained some interest on cave fishes, because later in life he published a number of popular articles on the topic (e.g., Girard 1888).

With these species at hand, blindness and depigmentation among fishes had become synonymous with cave life which, in turn, led to inaccurate assumptions and misleading information. That was the case with a new 'species' of cave fish described by Edward Drinker Cope (b. Philadelphia, Pennsylvania, 28 July 1840; d.
Philadelphia 12 April 1897). He published a paper on what he thought to be a new species and genus of troglomorphic fish, 'Gronias nigrilabris ' (Figure 7), from Pennsylvania (Cope 1864, p. 231). Although he did not present any evidence that such fish had been captured in the hypogean environment, he was quick to suggest that such fish 'is supposed to issue from a subterranean stream, said to traverse the Silurian limestone in that part of the Lancaster county, and discharge into the Conestoga'. Cope was known for his hasty conclusions and the superficiality of some of his work (Romero \& Romero 1999). Further studies have shown that the specimens on which he based this description were specimens of Ictalurus nebulosus that had eyes present which were asymmetrically developed - probably as a result of a teratological condition. Unfortunately his assertion on this fish continued to be repeated in the literature until recently (see Romero 1999b for full history of this misconception).

Thus, by the end of this period what we have are the descriptions of four species of troglomorphic fishes, two from the United States and two from Cuba, as well as a number of morphological studies about them. Absent from this period were evolutionary discussions. That would soon change. 


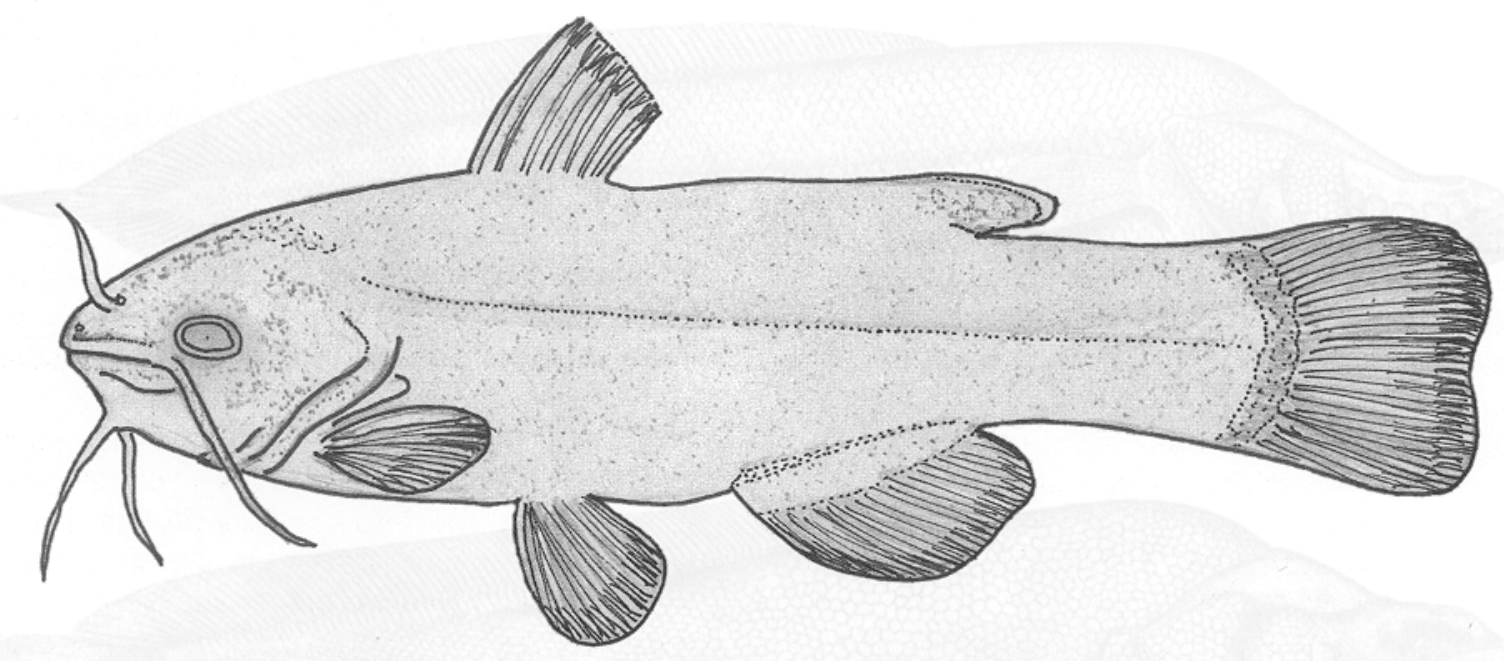

Figure 7. 'Gronias nigrilabris', which, according to Cope, was a 'blind' cave silurid. Drawing by Olga Mayayo.

\section{American neo-Lamarckism (1868-1919)}

The divide between this and the previous era was marked by two major historical events. The first was the American Civil War (1861-1865), which paralyzed scientific field activity in those areas where hypogean fish had been found. The second was the publication of On the Origin of Species (Darwin 1859). This period was also marked by the dominance, for the first time, of a generation of U.S.-born ichthyologists. Together with a few European expatriates, they began cataloguing the fish fauna of North America at the same time that the United States began the systematic exploration of the West through efforts such as the Mexico Boundary and Pacific Railroad Surveys (Hubbs 1964). Although some new species were described during this time, the intellectual era of American neo-Lamarckism was characterized by the usage of cave fauna in general, and troglomorphic fishes in particular, to advance this view of evolution.

Charles Darwin (b. Shrewsbury, England, 12 February 1809; d. Downe, Kent, England, 19 April 1882) wrote on cave fauna based on the observations made of European cave animals by the Danish naturalist Jorgen C. Schiodte (1815-1884) and the observations of American cave fauna of James Dwight Dana (1813-1895) as explicit support for evolution. He noted that cave fauna was more closely related to the fauna of the surrounding regions than elsewhere, as is the case for fauna of other isolated habitats. Thus, he argued that the cave fauna descended from the fauna of the surrounding region, "the colonists having been subsequently modified and better fitted to their new homes' (Darwin 1859, p. 403). At first Darwin considered the mechanisms of both natural selection and disuse to explain troglomorphic features, i.e., enlargement of some sensory systems and appendages for the former; blindness and depigmentation for the latter. To Darwin this suggested a "contest ... between selection enlarging and disuse alone reducing these organs' (op. cit., p. 296). However, in the third edition of the Origin (Darwin 1861) he de-emphasized the importance of natural selection, eliminating the speculation of a 'contest' between selection and disuse. This is important to keep in mind because, as we will see below, the members of the American neo-Lamarckian school closely followed Darwin in their interpretation of the mechanisms producing troglomorphic characters.

Darwin went back to much earlier explanations of evolutionary mechanisms and shielded the understanding of the evolution of cave fauna from more modern interpretations. This gave researchers of cave organisms arguments to support the 'use and disuse explanation'. In many ways, Darwin maintained a modified version of the Great Chain of Being (Bowler 1984, pp. 55-59), which was championed by the Swiss naturalist Charles Bonnet (1720-1793) and the French Philosopher Jean-Baptiste Robinet (1735-1820). They were followed by Jean Baptiste Chevalier de Lamarck (b. Bazentin-le-Petit, Picardy, France, 1 August 1744; d. Paris, France, 28 December 1829), again firmly planted into the Chain of Being tradition. Lamarck argued that organisms experience 'needs' (besoins) which were brought about by the environment and 
triggered fluids (including electricity) which, when circulated in the body, enlarged or developed the appropriate organ. In 'higher' animals, a crucial causal factor was the 'inner consciousness' (sentiment interieur), which makes parts respond and develop. This resulted in the inheritance of derived characters (Ruse 1996, p. 48). As we will see, even long after the development of the Modern Synthesis, this philosophy and its jargon (e.g., 'regressive evolution') would continue to be strongly imbedded in the research of hypogean fishes and in cave fauna in general.

The neo-Lamarckian period of hypogean fish research was dominated by three figures: Packard, Putnam, and Eigenmann. Alpheus Spring Packard, Jr. (b. Brunswick, Maine, 19 February 1839; d. Providence, Rhode Island, 14 February 1905) (Figure 8) studied under Agassiz and was his assistant from 1862 to 1864 at the Museum of Comparative Zoology. He received his M.D. from the Maine Medical

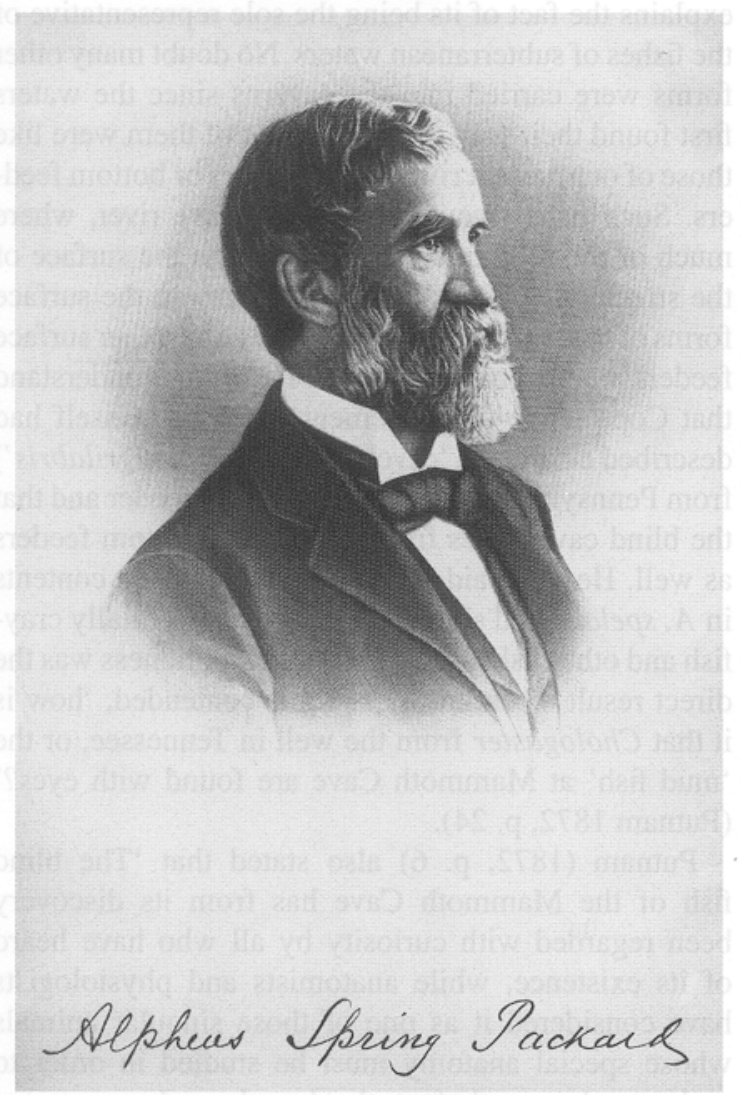

Figure 8. Alpheus Spring Packard, Jr. (courtesy of the Ernst Mayr Library of the Museum of Comparative Zoology, Harvard University @President and Fellows of Harvard College).
School at Bowdoin College in 1864. After breaking with Agassiz in the so-called 'Salem Secession' he went on to become a leading figure of American neoLamarckism which he championed from his positions at the Boston Society of Natural History, the Peabody Academy of Sciences at Salem, Massachusetts, and at Brown University (Dexter 1965, Bocking 1988). It was Packard who coined the term 'neo-Lamarckism' and called Lamarck 'the real founder of organic evolution' (Packard 1901, p. v).

In 1867, together with Edward Sylvester Morse and Alpheus Hyatt - also former Agassiz students Packard founded The American Naturalist, the journal that published the most articles on cave fauna during the nineteenth century. He first examined Mammoth Cave specimens after the Indianapolis meeting of the American Association for the Advancement of Science when many of the participants visited that cave. He published an account of its fauna the same year. The Mammoth Cave fauna, including its fish, convinced him of their usefulness as a demonstration of evolution. 'We trust naturalists the world over will be led to explore caves with new zeal.' For him, the highest interest was the impact that these studies could have on evolution (Packard 1871, p. 761). In 1874 he was associated with the Kentucky Geological Survey, which intensified his interest in the fauna of Mammoth Cave and other caverns in the Midwest regarding which he produced several publications (e.g. Packard 1888).

Packard, like Cope, thought that cave fauna was of very recent origin and that the loss of certain organs was compensated by the hypertrophy of others. Packard's views were not in opposition to those of Darwin himself, but to the neo-Darwinians like August Weismann (1834-1914) and Edward Ray Lankester (b. London, England, 15 May 1847; d. London, 15 August 1929). Lankester, influenced by German biologist Anton Dohrn (1840-1909), wrote that blindness among cave animals was due to a special kind of natural selection. He began with the assumption that some animals are, by chance, born with defective eyes. Occasionally a few animals, some of which have normal eyes and some defective eyes, fall or are swept into caves. In each generation, those that have good eyes were able to see the light and escape, and eventually only those that are blind remained in the cave (Lankester 1893). Lankester also believed that one can find organisms degenerating ontogenetically and phylogenetically. He defined 'degeneration' as 'a loss of organization making the descendent far simpler or lower in structure than its ancestor', a phenomenon that he found widespread. 


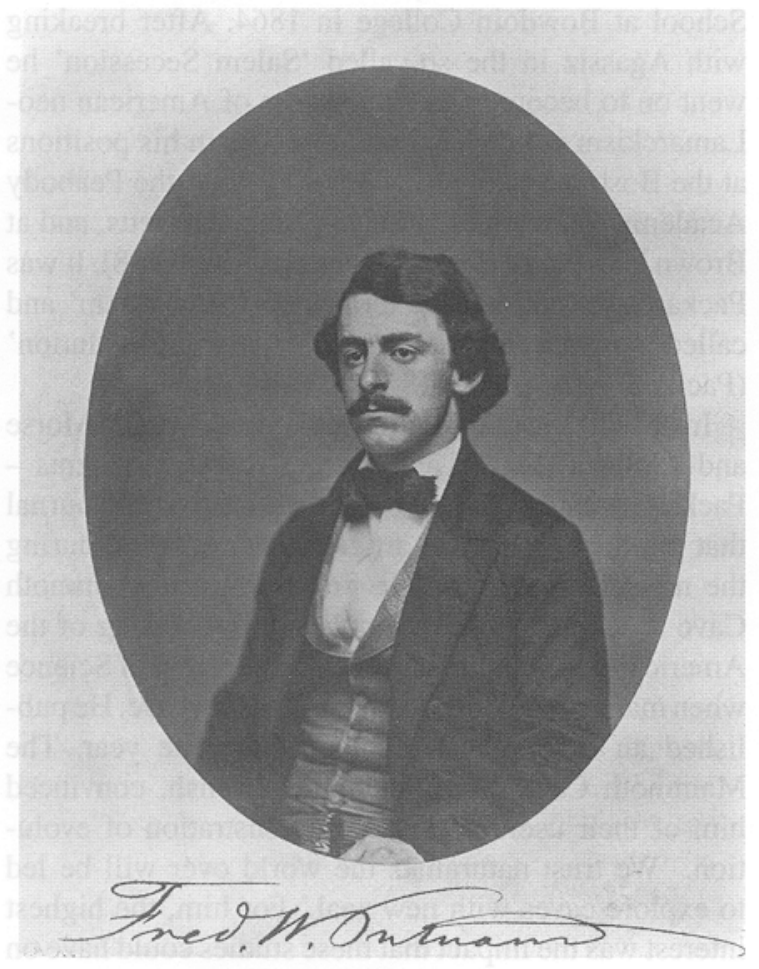

Figure 9. Frederick Ward Putnam (courtesy of the Ernst Mayr Library of the Museum of Comparative Zoology, Harvard University (CPresident and Fellows of Harvard College).

'Any new set of conditions occurring to an animal which render its food and safety very easily attained, seem to lead as a Rule of Degeneration' (Lankester 1880 , p. 33).

The other leading figure of this time was Frederic Ward Putnam (b. Salem, Massachusetts, 16 April 1839; d Cambridge, Massachusetts, 14 August 1915) (Figure 9). Like Packard, Putnam studied under Agassiz and was his assistant until a split from him during the 'Salem Secession'. He was much more of an ichthyologist than Packard was, occupying such positions as curator of ichthyology and/or vertebrates in many institutions including the Boston Society of Natural History, the Essex Institute, the Peabody Academy of Science, and Harvard's Museum of Comparative Zoology. Of all of these experiences, it was his position in 1874 as Assistant of the Kentucky Geological Survey that brought him in direct contact with hypogean fishes.

Like Packard, Putnam first visited Mammoth Cave to collect fishes in 1871 after the adjournment of the meeting of the American Association for the Advancement of Science. He returned in 1874 following an invitation from Nathaniel S. Schaler, another of Agassiz's students who, as director of the Kentucky State Geological Survey, appointed Putnam as special assistant to the Survey that year. He made the first large collection of Mammoth Cave fishes from Kentucky (22 in total) in October 1874 , some of which were displayed alive at the Essex Institute. Interestingly, the first public exhibition of a live amblyopsid took place not in the United States but in the Dublin Zoological Gardens, Ireland, sometime in 1870 (Baird 1872, Putnam 1874).

Although less known than Packard because he was not very much inclined to provide sweeping generalizations or engage in theoretical discussions, Putnam expressed a high degree of critical thinking. For example, he criticized Cope's interpretation that A. spelaea was able to survive in those waters because it had 'the projecting under jaw and upward direction of the mouth renders it easy for the fish to feed at the surface of the water (...) This structure also probably explains the fact of its being the sole representative of the fishes of subterranean waters. No doubt many other forms were carried into the caverns since the waters first found their way there, but most of them were like those of our present rivers, deep waters or bottom feeders. Such fishes would starve in a cave river, where much of the food in carried to them on the surface of the stream...' He asked then: where are the surface forms of the 'surface feeders'? How come other surface feeders are not found in caves? He did not understand that Cope made this statement when he himself had described an alleged 'cave' fish ('Gronias nigrilabris') from Pennsylvania which was a bottom feeder and that the blind cave fishes from Cuba were bottom feeders as well. He also said that studies of stomach contents in A. spelaea had shown that they eat essentially crayfish and other fishes. He asked that if blindness was the direct result of darkness, as some contended, 'how is it that Chologaster from the well in Tennessee, or the 'mud fish' at Mammoth Cave are found with eyes?' (Putnam 1872, p. 24).

Putnam (1872, p. 6) also stated that 'The blind fish of the Mammoth Cave has from its discovery been regarded with curiosity by all who have heard of its existence, while anatomists and physiologists have considered it as one of those singular animals whose special anatomy must be studied in order to understand correctly facts that have been demonstrated from other sources; and, in these days of the Darwinian and development theories, the little blind fish is called forth to give its testimony, pro or con.' He viewed the 
amblyopsids as former marine and saltwater estuary fishes that were slowly trapped in that geographical area. He substantiated this hypothesis by pointing out that the eyed amblyopsid $C$. cornuta, was 'now living in the ditches of the rice fields of South Carolina, under very similar conditions to those under which others of the family may have lived in long preceding geological time; and to prove that the development of the family was not brought about by the subterranean conditions under which some of the species now live, we have the ones with eyes living with the one without, and the South Carolina species to show that a subterranean life is not essential to the development of the singular characters which the family possess'. He further supported this hypothesis by mentioning that the Cuban blind cave fishes belonged to the genera 'with their nearest representative in the family a marine form, and with the whole family of cods and their allies, to which group they belong, essentially marine'. Putnam (op. cit., pp. 22-23) also described a new species of amblyopsid, Chologaster agassizi, as the fifth troglomorphic fish. By the year of his last publication on hypogean fishes (Putnam 1874), he switched careers from ichthyology to archaeology after he was appointed as the Curator of the Peabody Museum of American Archaeology and Ethnology at Harvard University.

All discussions on the evolution of cave fauna in general and hypogean fish in particular, at the time of Packard and Putnam, took place under the influence of the so-called 'Hyatt-Cope' position or school which was based on drawing parallels between embryology and phylogeny. Cope had little time for natural selection (e.g., Cope 1864) and seeing adaptation as part of the picture, plumped for Lamarckism. Central to Cope's vision of the biological world was the way in which organisms fall in trends. 'The method of evolution has apparently been one of successional increment or decrement of parts along definite lines' (Cope 1896, p. 24). This is what was later called orthogenesis, the view that evolution has a momentum of its own that carries organisms along certain tracks. Cope also proposed the 'Law of the Unspecialized': when an organism has gone too far down a particular phylogenetic path (as cave species do, according to him), especially a particular adaptively specialized path, it can never pull itself out and evolve into an altogether new and fruitful form (Cope 1896, pp. 172-174).

Aplheus Hyatt (b. Washington, D.C., 5 April 1838; d. Cambridge, Massachusetts, 15 January 1902) (Figure 10), whose more prominent position was that of director of the Boston Museum of Natural History,

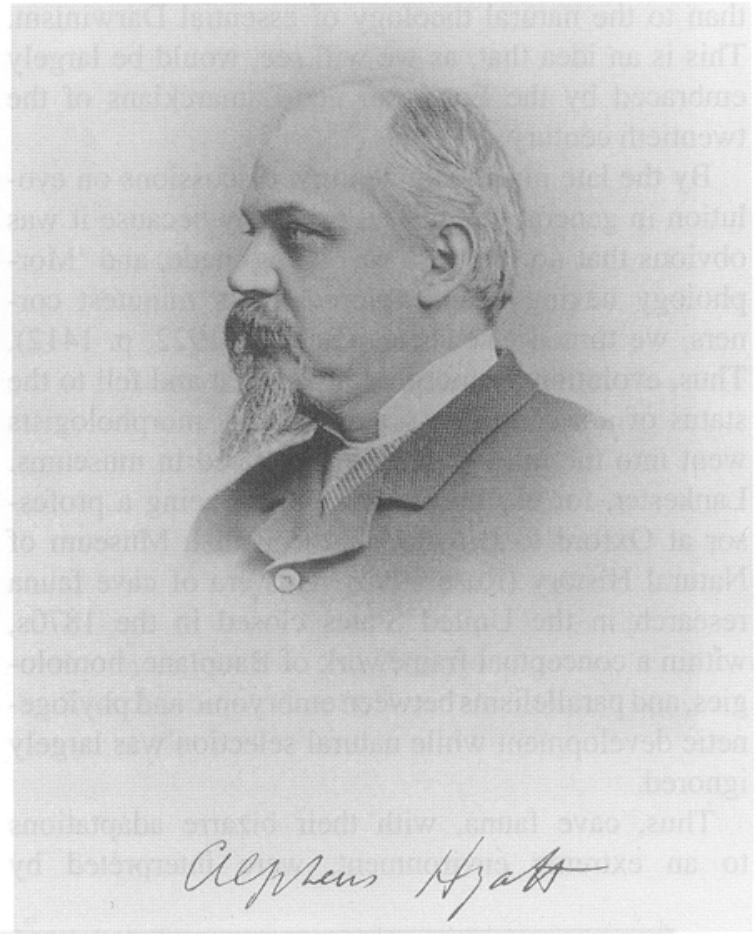

Figure 10. Alpheus Hyatt (courtesy of the Ernst Mayr Library of the Museum of Comparative Zoology, Harvard University (C) President and Fellows of Harvard College).

visited Mammoth Cave in September 1859, much earlier that his contemporary colleagues, and collected seven specimens of $T$. subterraneus that Putnam later studied (Bocking 1988). Hyatt's ideas can be summarized as follows: (1) just as the individual eventually declines into old age and senescence, so also the group declines into old age and senescence; (2) before extinction, there is degeneration of species; (3) change is a function of the speeding ('acceleration') or slowing ('retardation') of development which, in turn, is propelled by use and disuse (Hyatt's 'Law of Acceleration', is a direct descendant of Haeckel's 'Principle of Recapitulation'); (4) degeneration is therefore a virtually inevitable outcome of the evolutionary process, since any organism tends to collapse into old age, and it is a matter of time before this decay is delayed in development until adulthood (for a summary of Hyatt's ideas see Brooks 1909). Thus, Hyatt worked within a progressionist framework, a kind of Americanized Naturphilosophie. After all, the kind of evolutionism expressed by Agassiz's students and those under their influence (which was quite vast) had more to do with the transcendentalism of the German Naturphilosophie 
than to the natural theology of essential Darwinism. This is an idea that, as we will see, would be largely embraced by the European neo-Lamarckians of the twentieth century.

By the late nineteenth century, discussions on evolution in general languished primarily because it was obvious that no progress was being made, and 'Morphology having been explored in its minutest corners, we turned elsewhere' (Bateson 1922, p. 1412). Thus, evolutionary morphology stalled and fell to the status of a second-rate science. Many morphologists went into the kind of science practiced in museums. Lankester, for example, moved from being a professor at Oxford to Director of the British Museum of Natural History (Ruse 1996). This era of cave fauna research in the United States closed in the 1870s, within a conceptual framework of Bauplane, homologies, and parallelisms between embryonic and phylogenetic development while natural selection was largely ignored.

Thus, cave fauna, with their bizarre adaptations to an extreme environment, were interpreted by
neo-Lamarckians as providing excellent evidence for the effect of the environment upon the evolution of organism. Cave fauna could demonstrate the power of the physical environment as an evolutionary factor, capable of maintaining an organism's adaptation to its changing surroundings. Packard attributed more evolutionary importance to the direct effect of the environment than to the effect of changes in habits. Cave research therefore helped to establish that the changing environment could be responsible for the underlying progressive trends in evolution that Packard saw in his work in embryology.

By the 1870's Wyman, Packard, Putnam, and the rest stopped publishing on hypogean fishes. The topic seemed to have been conceptually exhausted. Nearly 20 years were to pass before anyone else would show an interest in the topic.

The next relevant figure in the history of hypogean fish research was Carl H. Eigenmann (b. Flehingen, Beden, Germany, 9 March 1863; d. Chula Vista, California, 24 April 1927) (Figure 11). Influenced by David Starr Jordan (a student of Louis Agassiz's son,

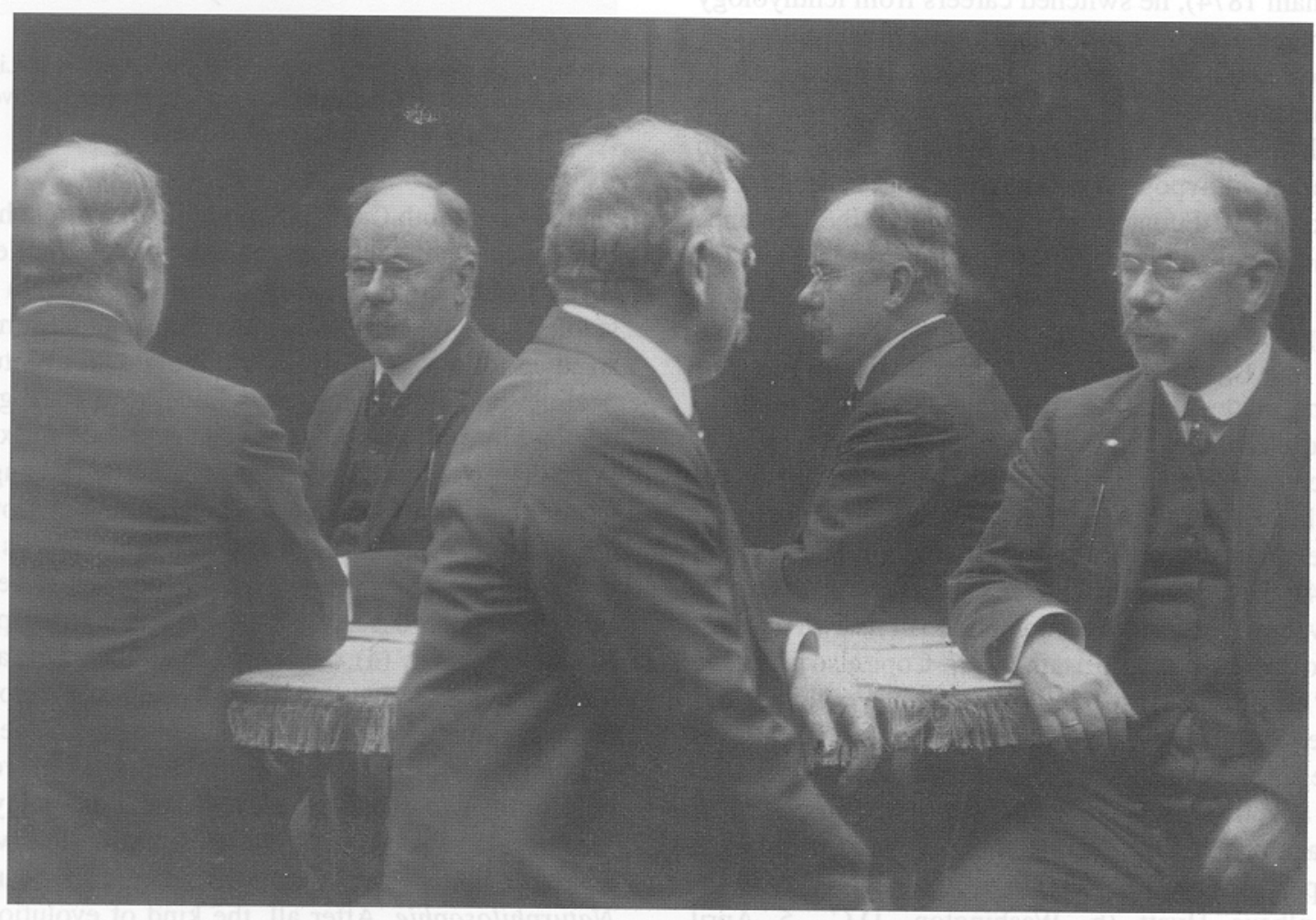

Figure 11. A little known picture of Carl. H. Eigenmann. The effect of this picture was probably achieved by making five different exposures. This picture is dated September 1914 (courtesy of the Smithsonian Institution, NMNH, Division of Fishes). 
Alexander), he became a biologist particularly interested in fishes. His first experience with troglomorphic fishes took place in 1886 while at Indiana University when he received a living blind fish taken from a well in Corydon, Indiana. The next year he married Rosa Smith (1858-1947), the first woman president of the scientific society Sigma-Xi. In 1889 they established residence in California where he was named Curator of the San Diego Natural History Society. There, his wife introduced him to the blind goby found among the rocks of the California coast, Typhlogobius califomiensis (see Eigenmann 1890 for a historical account of this encounter and how much it impressed him). In 1891 he was appointed Professor of Zoology at Indiana University, a perfect location to study the blind vertebrates of the caves in the nearby areas. This motivated him to devote a substantial part of his scientific career to the study of blind vertebrates, most of them in caves (Romero 1986b).

Between 1887 and 1909, much of his work was devoted to comprehending the process of the loss of visual structures in cave vertebrates. In May 1896 he visited Dalton's Spring (actually a cave-stream) where he secured 20 specimens of $A$. spelaea. This became his favorite collecting locality. In 1898, Eigenmann published the description of a new species of cave fish with rudimentary eyes from south-western Missouri, Amblyopsis rosae (= Typhlichthys rosae), which he named after his wife.

Eigenmann extensively visited the caves of Indiana, Kentucky, Texas, and Missouri in search of specimens for his work and in March 1902, he visited Cuba for the first time to secure cave specimens for his comparative studies. He had been working on fish reproduction in the past and quickly recognized that these two Cuban hypogean fish species were viviparous.

Contrary to Mammoth Cave, Eigenmann found the localities for the Cuban blind fish 'monotonous' (Eigenmann 1903). From 1906 to 1907 he did many laboratory studies in Europe, mostly in Germany, with the Cuban specimens he had collected. During this period he made plans to visit the Yucatán peninsula in Mexico because of persistent reports of a varied cave fauna in that part of the world. From 1898 to 1905 Eigenmann published at least 39 papers and abstracts on cave vertebrates, dealing mostly with developmental and anatomical aspects of vision loss in fishes, salamanders, lizards, and mammals as an attempt to understand the underlying process of blindness among hypogean animals. All this research was summarized in his Cave Vertebrates of North America (Eigenmann 1909), a 341-page, 30-plate monograph.

Although a taxonomist by training, Eigenmann quickly sought answers to the issues of the origin and evolution of the cave fauna. Originally a neoLamarckian, Eigenmann thought that the reduction or disappearance of organs among cave animals was a case of convergent evolution, i.e., well-defined conditions of the subterranean environment facilitate the evolutionary changes leading to blindness and depigmentation in a variety of vertebrate and invertebrate organisms which come to inhabit them. He pointed out that lack of pigmentation had to be understood as the combination of genetically fixed and epigenetically (environmentally-influenced) determined characters; in other words, that although a character was genetically determined, its degree of development may vary under certain light conditions. For Eigenmann cave evolution was essentially 'degenerative' and all successful cave-invaders were somehow pre-adapted to that medium. The origin of caves and of blind fauna'were two distinct questions because of his experience with the blind fish found among the rocks of California's seacoast. He insisted on a strong link between ontogeny and phylogeny and his constant use of terms such as 'phyletic degeneration' indicates that he held orthogenetic views. He followed Herbert Spencer's (1820-1903) idea that cave faunas were not the result of 'accidents' but rather the product of an active process of colonization (Eigenmann 1909).

His last contributions in the field were the descriptions of a new species of blind fish, Trogloglanis pattersoni, from the artesian waters of San Antonio, Texas (Eigenmann 1919). This description was based on a specimen collected by G.W. Brackenridge of San Antonio, who gave the fish to J.T. Patterson, a professor at the University of Texas, who in turn sent it to Eigenmann at Indiana University.

Two more hypogean species were discovered during this period: Phreatobius cisternarum by Goeldi (1905) and Pimelodella kronei (= Typhlobagrus kronei) by Miranda-Ribeiro (1907), both from Brazil. Probably due to geography, the discovery of these species never made any important impact on general discussions of biological concepts.

Thus, from 1866 on, the neo-Lamarckian school flourished and found its strongest supporters among American naturalists interested in cave fauna (Figures 12, 13). Although Barr (1966) called the beginning of this era the 'Neolamarckian revolt against 


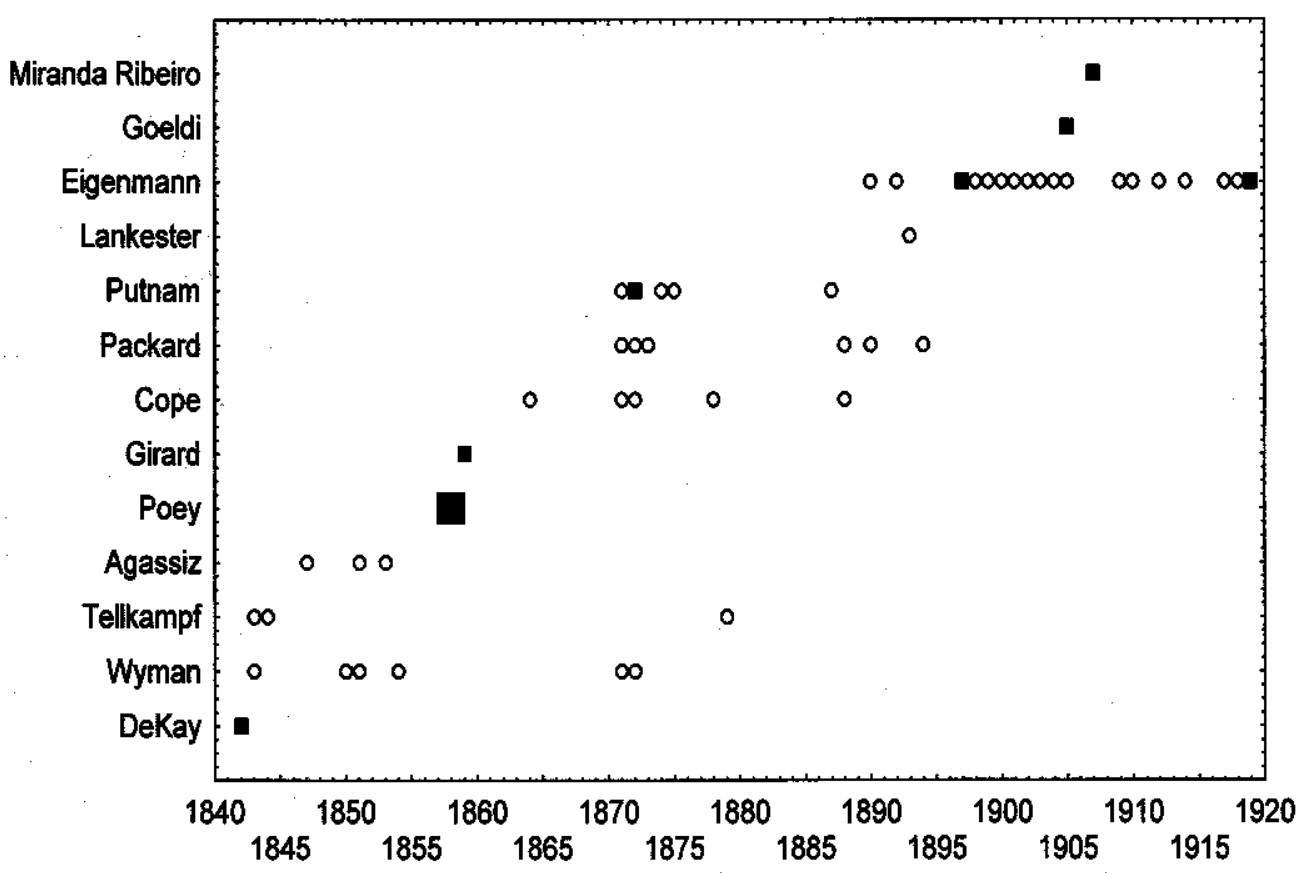

Figure 12. Time-line graph of major papers on hypogean fishes published between the first scientific description of a troglomorphic one, Amblyopsis spelaea in 1842 , to right before the beginning of the typological era. Squares represent papers describing new species. The larger square for Poey represents a single paper describing two species. Open circles are papers on anatomy and evolution. Notice the divide created by the American Civil War (1861-1865) which interrupted virtually all research efforts.

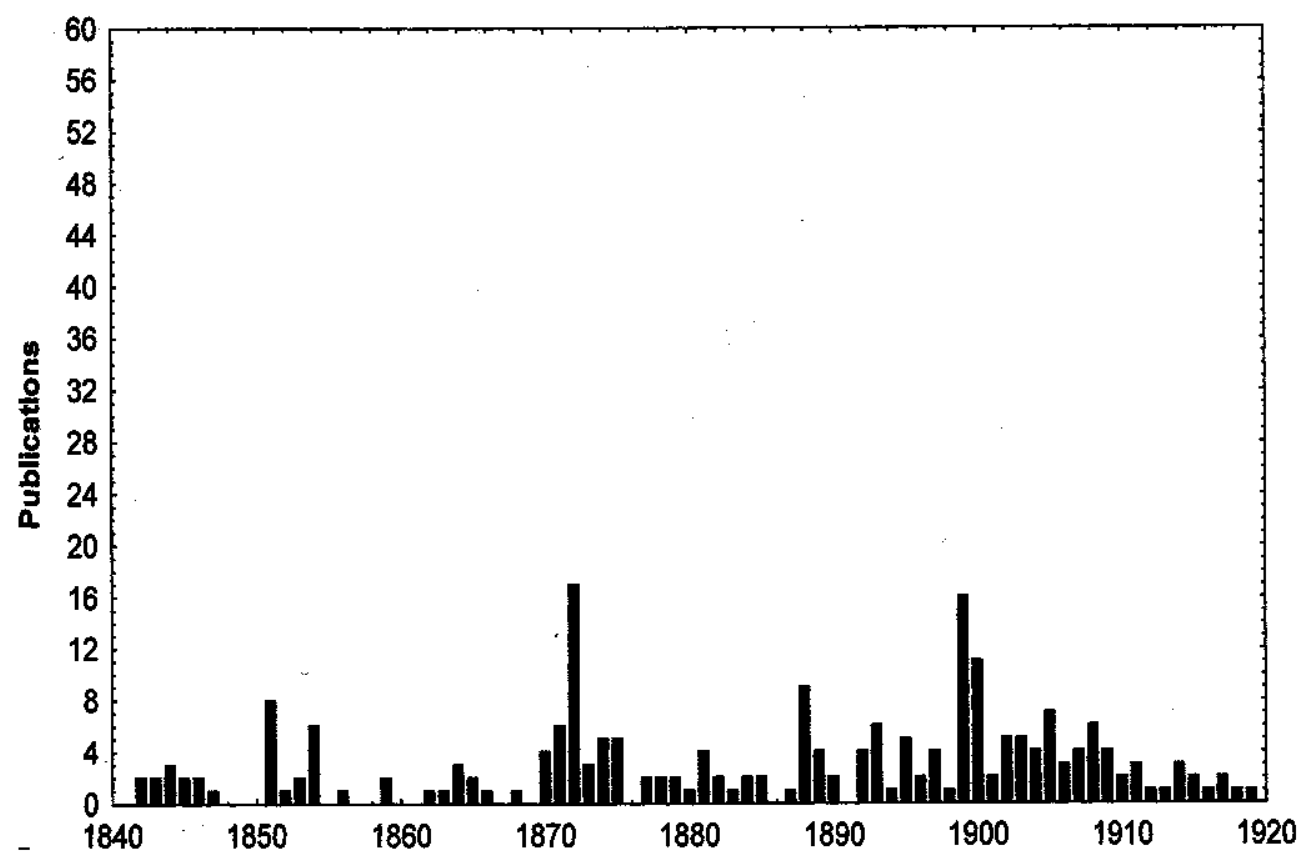

Figure 13. Number of publications on hypogean fishes between 1842 and 1919 . The 'pulse' for the 1870's represent the high point of the neo-Lamarckian school's interest in these animals. The one for the early 1900 's is almost entirely due to the intense publishing activity by Carl H. Eigenmann. 
Darwin's theory of evolution by means of natural selection', the fact of the matter is that those neoLamarckians were very much in line with what Darwin himself said, particularly in later editions of his Origin of Species.

\section{Dominance of typological thinking (1921-1940)}

This period is characterized by three trends: (1) the incremental discovery of new species, all of them outside of the United States, which gave a broader perspective not only geographically but also taxonomically to the diversity of hypogean fishes, since most of these new species belonged to fish families with not previously reported hypogean representative; (2) the absence of researchers who devoted considerable part of their research to this topic, as Wyman, Packard, Putnam and Eigenmann had done before. During this period all authors of hypogean fish papers spent very little time on the subject, mostly because they were studying the fish fauna of a particular area where troglomorphic fishes were found. The only possible exceptions to this were Jacques Pellegrin $(1873-1944)$ and Luisa Gianferrari (1890-1977) who published a handful of papers on the subject. Yet, those papers were the product of their interest on the fish fauna of a particular geographical region more than the study of hypogean fishes per se; (3) most of the new species/populations discovered were given a new generic status based almost exclusively on the fact that they lacked eyes and pigmentation.

Of the 12 new species/populations described during this period (Table 1, Figure 14), six were from Africa, three from Mexico, two from Japan and one from Trinidad, W.I. The new discoveries in Africa were propelled by the presence of European colonial powers in that part of the world and the specimens were collected by local colonial authorities. The ones in Mexico were carried out by American-born researchers venturing for the first time outside the United States. The ones from Japan and Trinidad were described by British researchers residing in the United Kingdom. The two new species from Japan were re-descriptions based on specimens collected by a Japanese researcher while the one from Trinidad was collected by a local natural historian.

The first description of a new species of troglomorphic fish for this period epitomizes the trend set by European researchers when dealing with African hypogean species. When King Leopold II of Belgium

\section{Published descriptions of troglomorphic species/populations of fish through time}

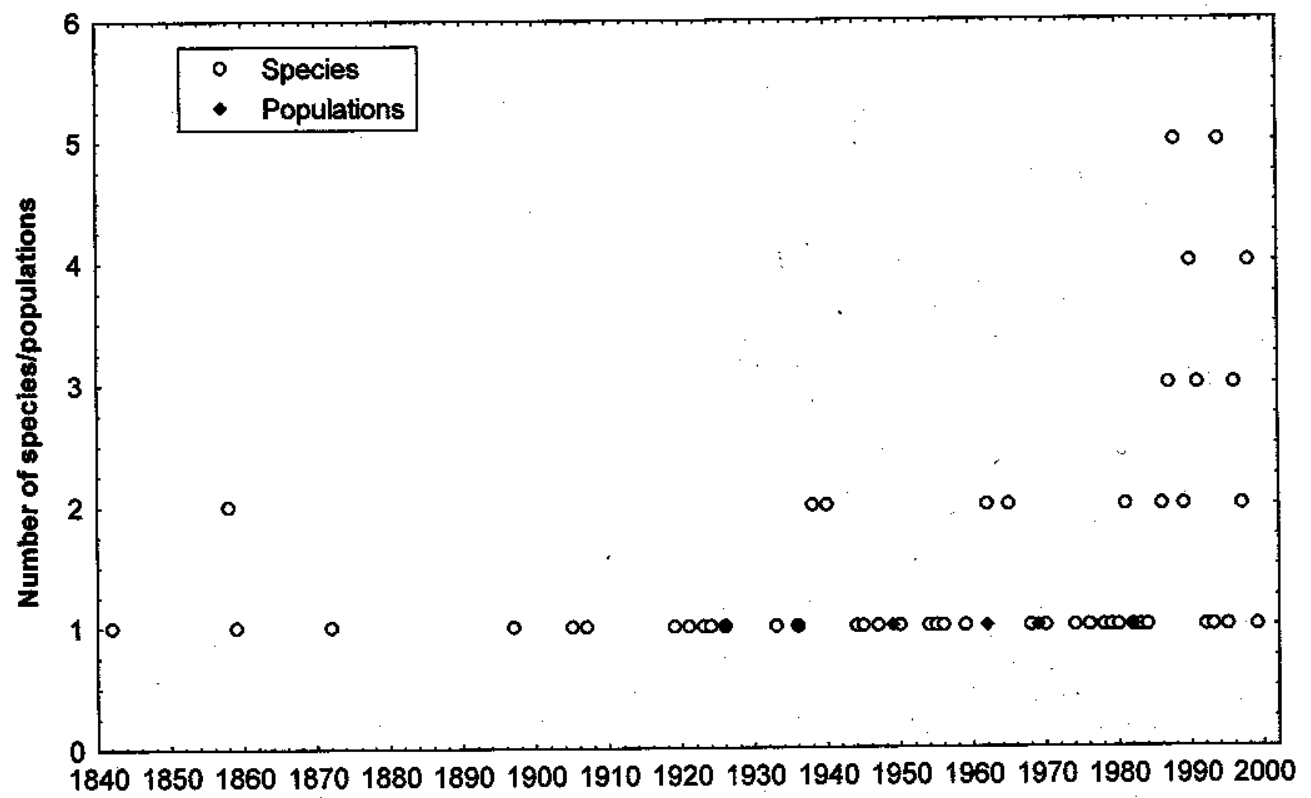

Figure 14. Published scientific descriptions of troglomorphic species/populations of hypogean fishes. There has been a steady number of new descriptions since the 1920's when the typological era started with description of new species mostly from Africa. The increased number in the late 1980's and throughout the 1990's is due to new discoveries in Asia, particularly in China. 
foresaw the importance of scientific research in Africa, he instructed voyagers and explorers to collect natural history information about the Congo. Not surprisingly, many Belgian officials collected and brought to Europe unknown zoological specimens that had never been scientifically studied. One of those specimens fell in the hands of George Albert Boulenger (b. Brussels, Belgium, 19 October 1858; d. Saint Malo, France, 23 November 1937) (Figure 15). He worked from 1880 until his retirement in 1920 at the British Museum. By then, Boulenger had published 877 papers totaling more than 5000 pages, as well as 19 monographs on fishes, amphibians, and reptiles in which he described 1096 species of fish, 556 species of amphibians, and 872 species of reptiles. He was considered the world's expert on African freshwater fishes despite the fact he had never been to Africa. Boulenger's only previous stint as researcher of cave animals had been a short note on the eye development of the cave salamander Proteus (Boulenger 1893).

In 1921, Boulenger received a blind and depigmented fish specimen from the Congo. He was quick to

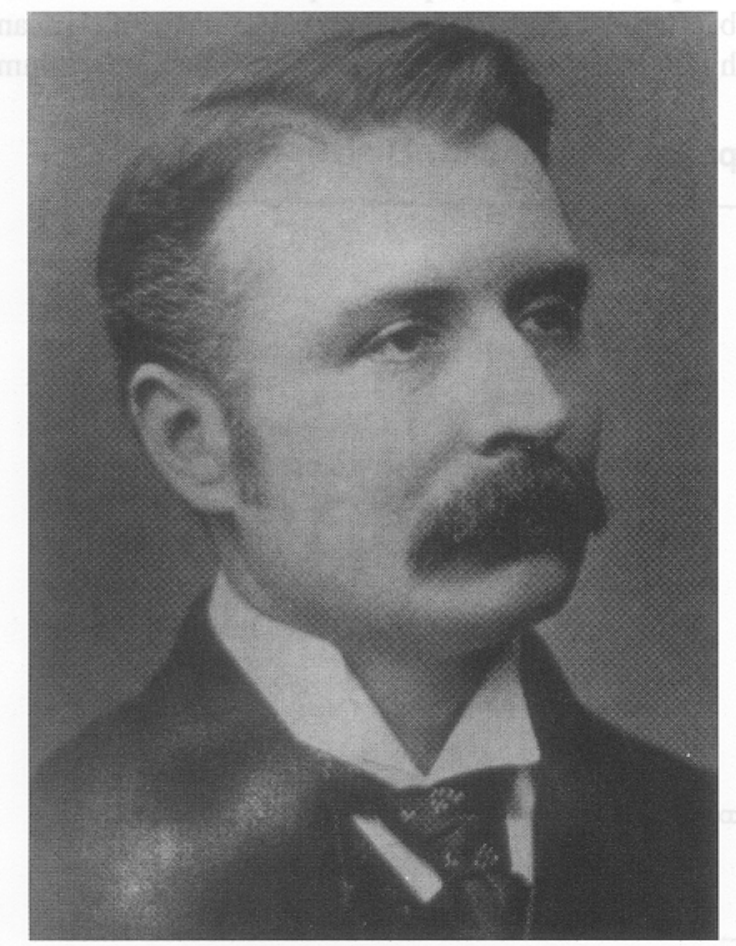

Figure 15. A young Georges Albert Boulenger about the time he started working at the British Museum of Natural History (courtesy of the Smithsonian Institution, NMNH, Division of Fishes). recognize its uniqueness since it did not seem closely related to any extant African epigean species. He named it Caecobarbus geertsii, from caeco $=$ blind, barbus $=$ barb, and geertsii, honoring a mysterious person, M. Geerts, who provided him with the specimen (Boulenger 1922). This species of fish may have been originally collected in 1915 by M. Delporte, probably the first European to see this fish. Soon this species became a celebrity in the world of cave fish research. Being easy to transport alive, many European scientists started to work on it. It became so famous that in May 1951 it was exhibited at the New York Aquarium (Romero \& Benz 2000).

The same can be said of other African hypogean fishes. Three were discovered in Somalia, collected by local colonial Italian officials, but then described by ichthyologists in museums of natural history of Italy (Uegitglanis zammaranoi Gianferrari, 1923, Phreatichthys andruzzii Vinciguerra, 1924, Barbopsis devecchii Di Caporiacco, 1926). Another was collected by a French explorer in Madagascar and sent to France for identification (Typhleotris madagascariensis Petit, 1933) and the last from Africa was collected in South Africa by a local physician and sent to the British Museum of Natural History (Clarias cavernicola Trewavas, 1936).

The case of the hypogean fish from Trinidad had a different twist. It was collected by a local and well-known naturalist, Friederick William Urich (1872-1936), who sent the specimens to London for identification. When received by the British Museum of Natural History in July 1924, they were given to John Roxborough Norman (1899-1944), who had published a few papers on the fishes of the nearby island of Tobago. Besides certain reduction in the eye size, this fish was extremely similar to Rhamdia quelen, a wellknown epigean fish common to northeastern South America and Trinidad. Fearing that the specimen could represent an accident of nature rather than a true new fish species, Norman requested two more specimens and Urich complied. He later published its report and named the fish Caecorhamdia urichi ( caeco = blind; rhamdia $=$ the genus of a catfish to which this cave fish seemed most related to; urichi $=$ honoring Urich, the collector) (Norman 1926). Since then, this fish species has consistently appeared in the lists of blind cave fishes of the world although today they are considered individuals of the common catfish $R$. quelen, a species of nocturnal habits showing different degrees of (but never complete) blindness and depigmentation (Romero \& 
Creswell 2000). This would be the first report of a cave fish population of an epigean species with certain degrees of troglomorphic features.

As previous examples demonstrate, during this period almost every cave fish population that was discovered, regardless of how close it looked to its epigean ancestor, had a new genus and species erected for it based on its taxonomic characters of blindness and depigmentation. This was the typological approach prevalent at that time, a derivative of the essentialist philosophy that has dominated Western thinking and was not replaced until after the Modern (Evolutionary) Synthesis of the late 1930s and early 1940s. As we.will see later, such thinking has been retained to certain extent in some quarters of hypogean fish research.

Besides the re-descriptions by Charles Tate Regan (1878-1943) of two Japanese hypogean fishes (Luciogobius pallidus and Luciogobius albus Regan, 1940), all the other discoveries during this period took place in Mexico by American born researchers. Since they operated intellectually and geographically independently from their European counterparts, and because their discoveries opened new doors to hypogean fish research, they deserve to be treated separately despite an overlap of a few years with the efforts of their colleagues elsewhere.

\section{American renaissance (1936-1960)}

The resurgence of hypogean fish research began around the time the typological period started to wind down. Although the discovery of new species continued in Asia, Africa, and Australia, it was the work of American-born scientists doing field studies outside the United States and experimental work in American institutions that introduced a renewed interest in the subject, particularly because aspects other than taxonomy and morphology were investigated. This period is characterized by more comprehensive studies which included ecology, physiology, and behavior. This was, in part, due to the fact that the species most suitable for these kinds of studies was discovered at the very. beginning of this era.

In 1936, Salvador Coronado, a young Mexican in charge of the Fish Culture Station at Almoloya del Rio near Mexico City, sent 75 fish collected at the La Cueva Chica (the little cave) to C. Basil Jordan, a fish dealer from Dallas, Texas. Coronado thought those animals were particularly interesting: blind and pinkish. Jordan was impressed because all of the fish arrived to Texas alive, something particularly interesting for someone whose business largely depended upon the ability for a fish to survive transportation.

Not being able to determine the species, Jordan sent (at least some of) the fish to William Thornton Innes (1874-1969), a well-known aquarist and aquarium writer. Strongly suspecting that he had a new species in his hands, Innes remitted on November 1936 the specimens together with Jordan's notes to Carl Leavitt Hubbs (b. Williams, Arizona, 18 October 1894; d. La Jolla, California, 30 June 1979) (Figure 16). Hubbs was, by that time, one of the most respected American ichthyologists who had been doing field work in Mesoamerica and whose knowledge on freshwater fish taxonomy was considered to be virtually encyclopedic.

It took Hubbs only a few weeks upon receiving the material to publish a joint article with Innes describing this fish from the characid family as a new genus and species: Anoptichthys (eyeless fish) jordani (honoring Jordan). As Hubbs himself put it, this was the 'most surprising, by far subterranean fish belonging to the family Characidae, of which no blind representative has ever been seen before' (Hubbs \& Innes 1936, p. 1).

Hubbs' surprise was manifold. First, it was most unusual to capture so many individuals of a cave fish species in a single locality; the amblyopsids, by that time the best known cave fish family, were not so abundant. Second, the fact that all 75 individuals had arrived in the U.S. alive and were easily kept in captivity said something about the potential of this species as a research subject (Innes 1937). Third, this cave characin did not grossly display the hyperdeveloped sensory organs quite common among other cave animals. Basically; it only differed from its likely ancestor, Astyanax fasciatus, in lacking eyes and pigmentation. Yet; in line with the typological thinking of the times, it was given a new generic and specific status.

This Mexican cave fish was so amusing that in both Mexico and the United States a great deal of interest arose. A group of the Mexican 'Escuela Nacional de Ciencias Biologicas' that included, among others José Alvarez (1903-1986) and Bibiano F. Osorio Tafall, began the exploration of the whole cave system for the area which now has about 30 localities containing this fish (Mitchell et al. 1977). As a matter of fact, two new populations, in addition to the one in La Cueva Chica, were given new specific names: Anoptichthys antrobius for the La Cueva El Pachón population (Alvarez 1946) and A. hubbsi for the La Cueva de los Sabinos 


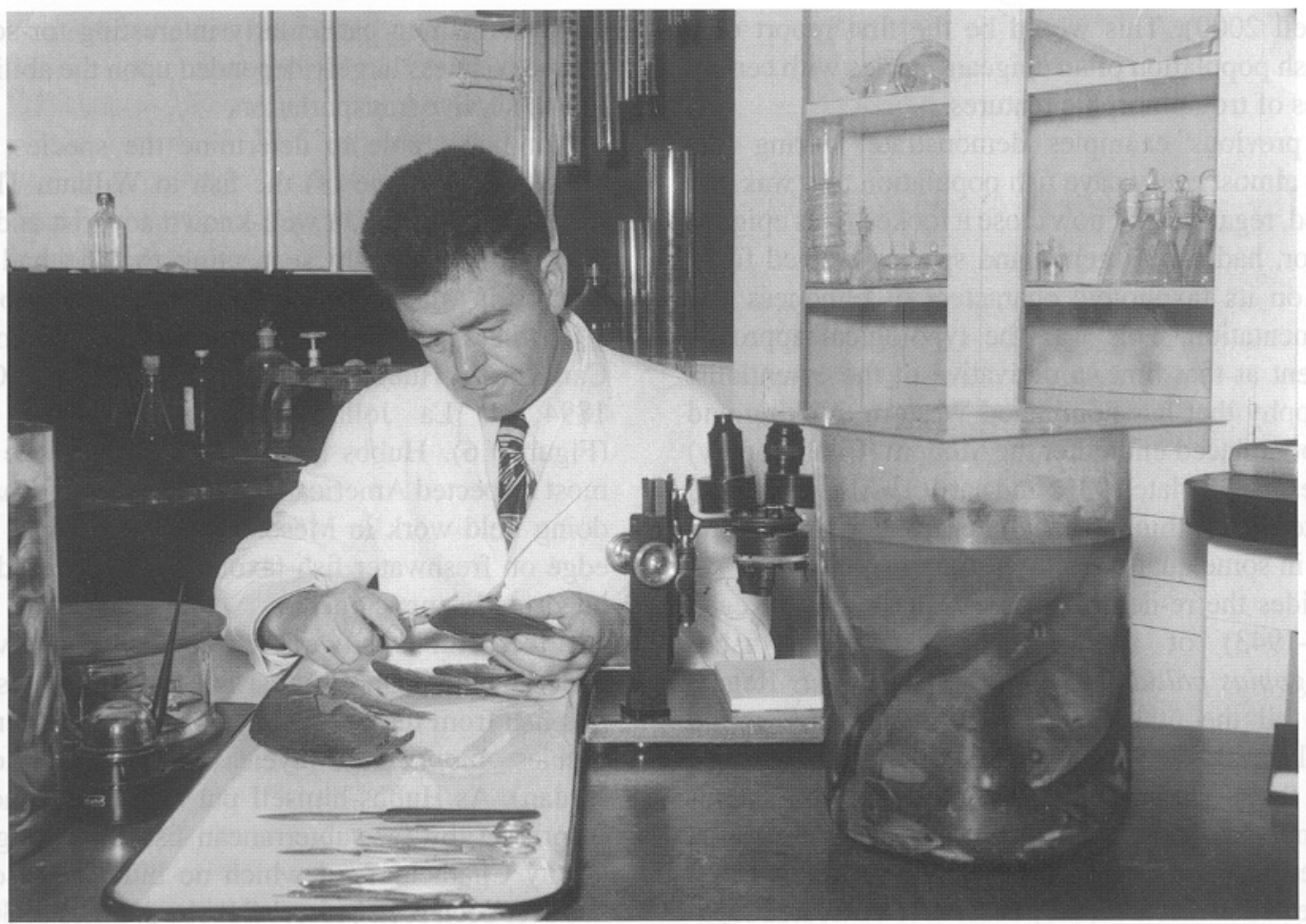

Figure 16. Carl Leavitt Hubbs in his laboratory at the Scripps Institution of Oceanography. This picture was taken in 1945, shortly after he had made his major contributions to hypogean fish research (courtesy of the Scripps Institution of Oceanography Library).

population (Alvarez 1947). As more cave populations were discovered, it became evident that this flow of specific names was leading nowhere and that all the troglomorphic fish should be considered as a single species.

Hubbs' hypogean cave research also comprised the Yucatán peninsula. Although there had been rumors of blind fishes from the cenotes (sink holes) of Yucatan (Girard 1888, Eigenmann 1909), it was not until the 1930s that organized scientific expeditions were carried out to explore this unique subterranean habitat. There, Hubbs found a number of epigean fish living in the cenotes, some of which showed certain degree of eye reduction and depigmentation and erected new subspecies status for them. But, more importantly, he also described two new troglomorphic species: Ogilbia pearsei (= Typhlias pearsei) and Ophisternon infernale ( $=$ Pluto infernalis) in a monographic publication in which he also reviewed all known information on cave fishes to that date (Hubbs 1938).

But it was his discovery of the cave characid that revitalized hypogean fish research. Hubbs \& Innes (1936) paper immediately attracted the attention of non-taxonomists. One of them was Myron Gordon
(1899-1959) an internationally known fish geneticist who had been associated with the New York Aquarium since 1938 . Since the late 1920 s he had a particular interest on the inheritance of normal and abnormal pigment cell growth, especially melanoma tissues, in fishes. Thus, in 1939 he visited the cave in which the fish had been discovered in Mexico. There he collected more individuals which he took to New York. This fish elicited the interest of his New York colleagues, among them Edward Bellamy Gresser (1898-1951), a practicing physician and a professor of ophthalmology at New York University. He used the laboratories of the New York Aquarium to study the histology of the cave Astyanax and published an article about it (Gresser \& Breder 1940). However, it was the co-author of that article who actually showed an intense interest on that species.

Charles Marcus Breder Jr. (b. Jersey City, New Jersey, 25 June 1897; d. Englewood, Florida, 28 October 1983), was the director of the New York Aquarium in 1939. After learning about the newly described fish and hearing Gordon's account of his recent trip to Mexico, Breder took the initiative of 


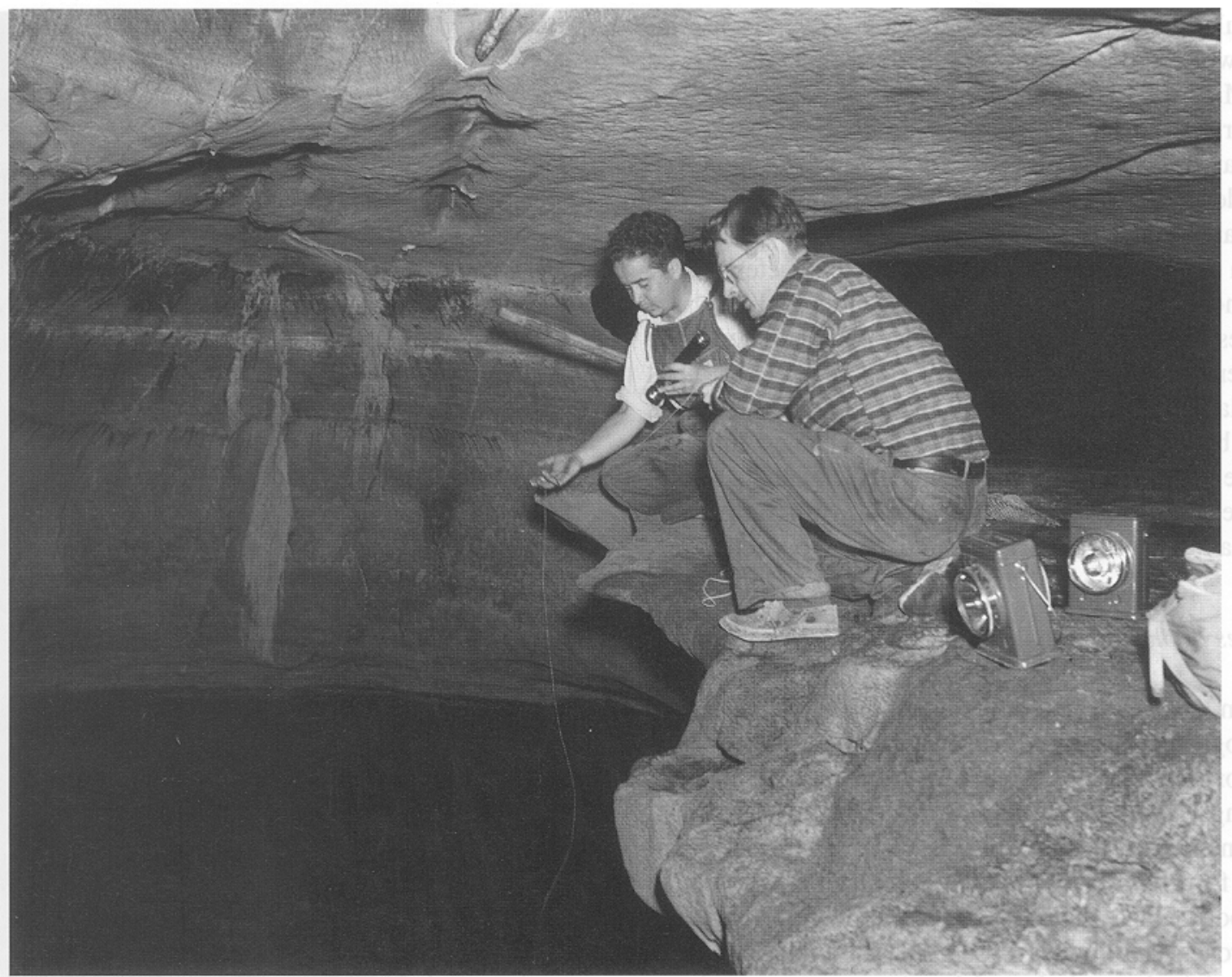

Figure 17. Picture of Charles Marcus Breder (right) and Salvador Coronado during their first expedition to 'La Cueva Chica' in Mexico in 1940. This will be the beginning of an extraordinary research program by Breder and his associates (photograph by Mary Edwards Braden, courtesy of the Wildlife Conservation Society).

organizing and leading an expedition to Mexico to perform field studies, obtain enough ecological information for a cave habitat display for the Aquarium, to shoot a documentary to be presented at the 1941 annual meeting of the New York Zoological Society, and, most importantly, to bring back enough fish to conduct extensive laboratory research (Breder 1942, Romero 1984, 1986a).

In January 1940, Breder held a meeting with other scientists where the whole expedition, known as 'The Aquarium Cave Expedition to Mexico,' was organized. By 11 March 1940, the group was already in Ciudad Vallés, near La Cueva Chica, the fish type locality (Figure 17). Despite the fact that most members of the expedition suffered from 'tropical fevers' (possibly histoplasmosis) after the trip, the expedition was a complete success (Bridges 1954).
Unlike many hypogean fish researchers before him, Breder was not particularly interested in systematics. Yet, in 1944 he was offered the chair of the Department of Fishes of the American Museum of Natural History and retired in 1965 (Atz 1986). Between 1940 and 1954 Breder (sometimes coauthoring with Gresser or Priscilla Rasquin, an ichthyologist at the American Museum of Natural History) published 17 papers (168 printed pages of information) on which Astyanax was the major subject of research. Most of the research concentrated on behavior, particularly responses to light and chemicals. But he also published on the fish sensory organs, metabolism, genetics, ecology, and evolution. Because the cave and the surface forms interbreed to produce fertile hybrids, he was the first who strongly suspected that the blind depigmented form was nothing but a remarkably locally-adapted 
population of the surface species Astyanax fasciatus well before advanced genetic techniques proved it. Many of Breder's contributions are still cited and several of his associates and students embarked in researching this cave fish. There is no question that Breder was the dominant figure in hypogean fish research in the 1940s and 50s (Figure 18).

In summary, this period was first characterized by the non-taxonomical research of Breder and his associates first at the New York Aquarium, and later at the American Museum of Natural History. Yet, not until the late 1950s did a number of European researchers also become interested in the genetics and evolution of these fishes which would, ultimately, signal the rebirth of neo-Lamarckian ideas about the evolution of cave fauna in general and hypogean fishes in particular.

\section{Times of philosophical conflict (1960-1990)}

From 1960 on, not only the number of papers on hypogean fishes increased (Figure 19), but also two major schools of thought started to develop very strongly. One was the school of orthogenesis which, essentially, utilized cave organisms as prime examples for 'regressive evolution', and the neo-Darwinian school, which tried to use the new concepts and approaches provided by the Modern Synthesis in order to explain the evolution of those very same organisms.

Let us begin with the orthogentic school. The notion of progress has been deeply embedded in evolutionary thought since pre-Darwinian times, and it was usually referred to as a matter of levels of complexity (Nisbet 1979, Ruse 1996). For Karl Ernst von Baer (1792-1876), for example, 'The more homogeneous the whole mass of the body is, so much the lower is the grade of its development. The grade is higher when nerves and muscles, blood and cell-substance, are sharply distinguished' (von Baer 1828, p. 207). We can see the concept of 'progress' also being used in the social sciences, particularly by those who held Marxist ideas (e.g., Demoor et al. 1897, Guillaume 1971). How was this idea embraced by students of cave faunas? For an answer, we need to look back to the American neo-Lamarckian school.

As we mentioned earlier, Cope introduced the idea that evolution was directed by trends and that 'The method of evolution has apparently been one of successional increment or decrement of parts along definite lines' (Cope 1896, p. 143). He, like other neoLamarckians, had little regard for natural selection;

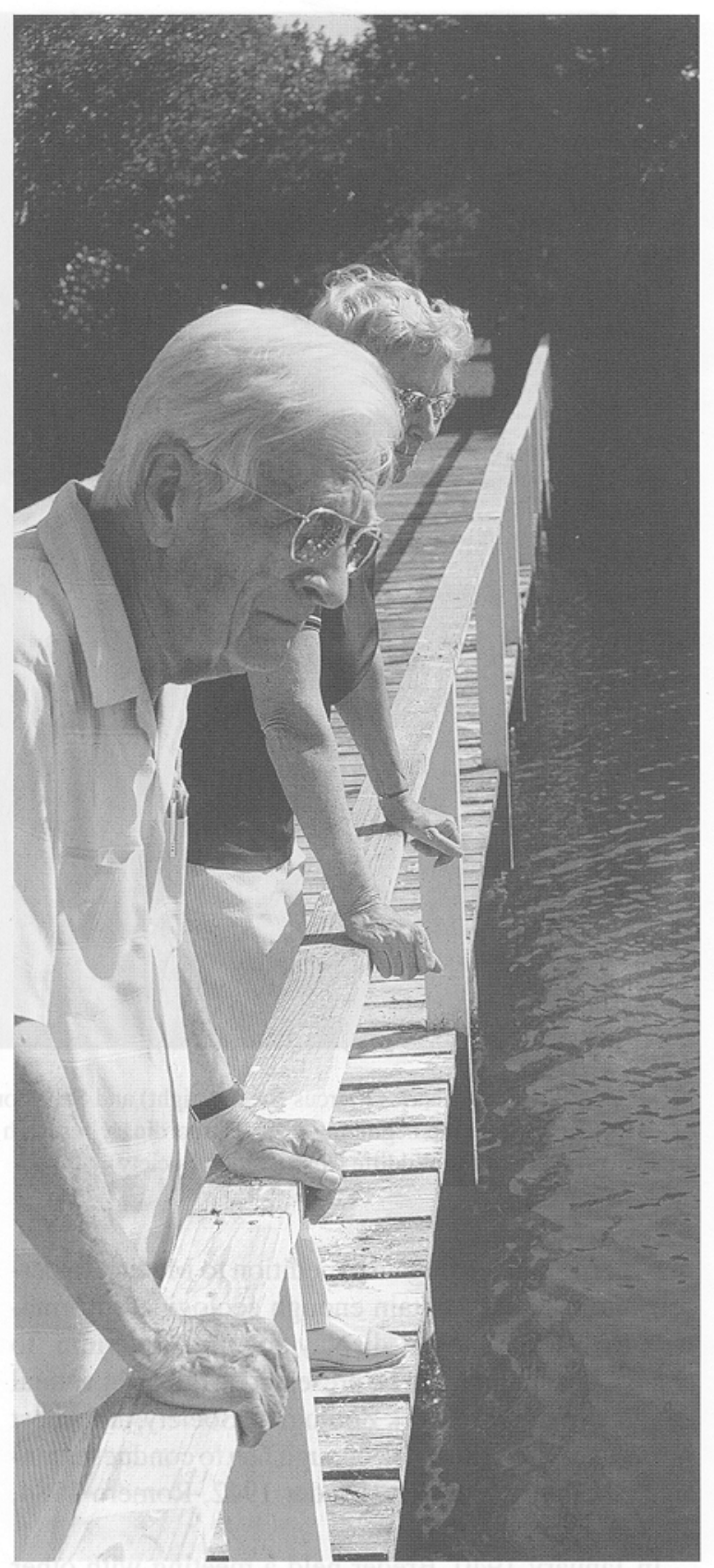

Figure 18. Charles Breder and his wife Priscilla next to their retirement home at Englewood on the 29 April 1979 (photograph by Eugene K. Balon).

thus, these 'natural' trends explained how evolution worked overall. That was the foundation of 'orthogenesis', i.e., the idea that there is a directionality in evolution. When an organism went too far in a 


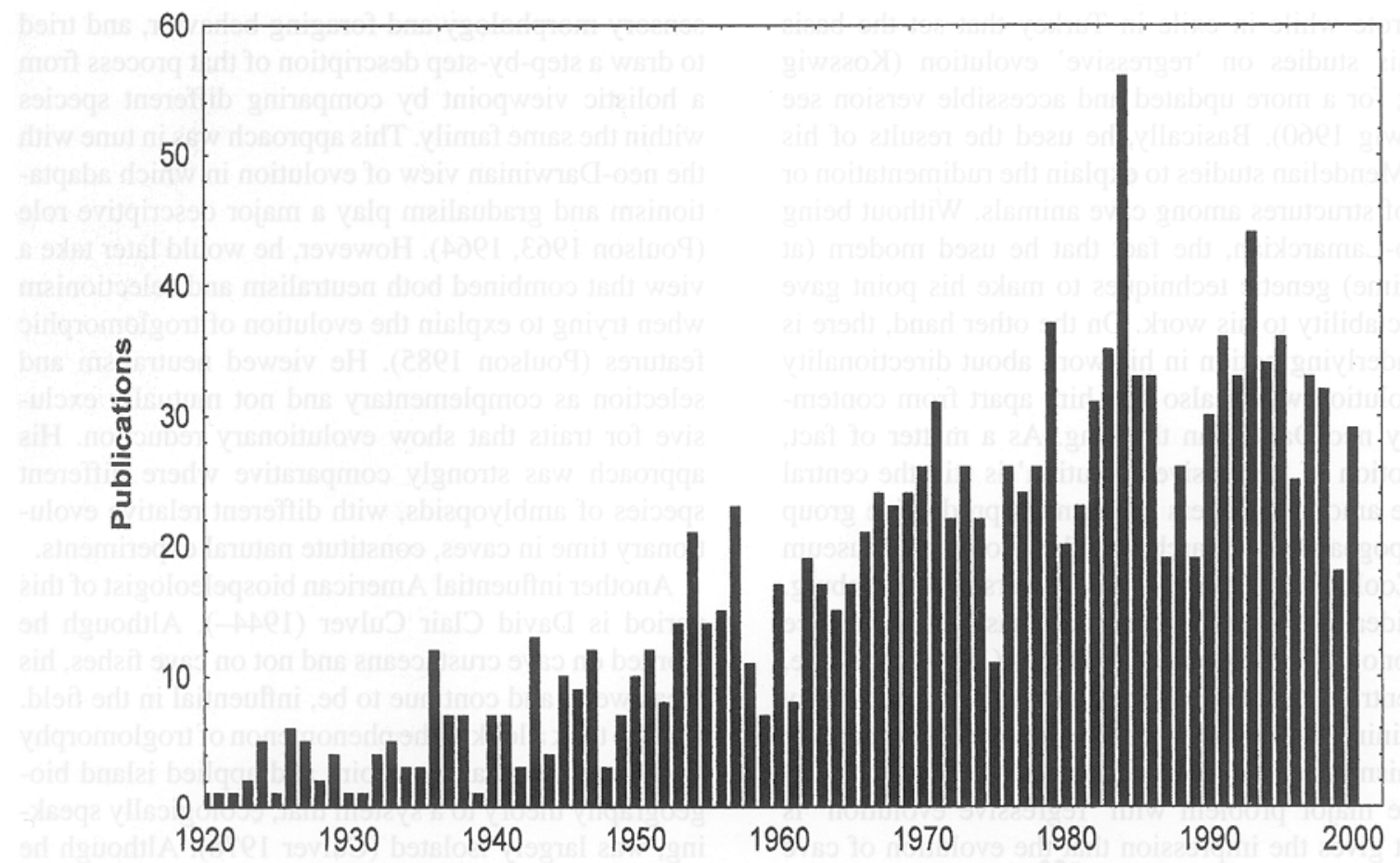

Figure 19. Number of publications on hypogean fishes from 1920 until 2000. From the beginning of the typological era in 1920 , there has been a steady stream of papers published on diverse aspects of hypogean fishes. The robustness of publication numbers from the late 1960's on is largely due to the members of the Hamburg School, whose interest was prompted by the pioneering research of Curt Kosswig.

particular direction or adaptively specialized path, like cave organisms, it could not reverse into a new form (Cope 1896, pp. 172-174).

With the re-discovery of Mendel's laws and under the influence of the Modern Synthesis, orthogenetic ideas advocated by neo-Lamarckians were temporarily dismissed, particularly among researchers in Englishspeaking countries. The resurgence of these ideas, however, started with the work of the Romanian biologist Emil G. Racovitza (1868-1947), considered by many as the founder of biospeleology and later continued in the 1960's by the French speleologist Albert Vandel (1894-1980). For Racovitza all cave organisms were 'preadapted' to the cave environment where 'the function creates the organ'. He was also a rabid' anti-neo-Darwinian (Motas 1962). For Vandel, the explanation of the evolution of cavernicoles was neither neo-Lamarckism (for which no empirical evidence could be found) nor neo-Darwinism (for which French researchers had little sympathy at that time). The explanation was 'organicism' which basically meant that 'all phyletic lines pass through several successive stages: the stage of the creation (...) [t] he stage of expansion and diversification, and finally the stage of specialization and senescence (...) The first stage of this cycle is a manifestation of progressive evolution and the last of regressive or gerontocratic evolution. The evolution of cavernicoles provides a particularly good example of regressive evolution which can occur only in the final stages of the evolution of animal lines' (Vandel 1964, p. 463). The application of these ideas to hypogean fishes can be clearly seen in Thinès (1969) book on cave and abyssal fishes. Curiously, these authors never fully acknowledged that orthogenesis was neo-Lamarckian in nature and was fully developed in the United States, but rather preferred to trace themselves back to French authors such as Henri Bergson (1859-1941), René Gabriel Jeannel (1879-1965), or Pierre Teilhard de Chardin (1881-1955).

It was a German researcher who popularized the whole notion of regressive evolution among cave animals in general and cave fishes in particular Curt Koswigg (b. Berlin, Germany, 30 October 1903; d. Hamburg, Germany, 29 March 1982). Since the 1930 's he had been working on cave fishes and showed an interest in evolutionary issues, but it was a paper 
he wrote while in exile in Turkey that set the basis for his studies on 'regressive' evolution (Kosswig 1949; for a more updated and accessible version see Kosswig 1960). Basically, he used the results of his own Mendelian studies to explain the rudimentation or loss of structures among cave animals. Without being a neo-Lamarckian, the fact that he used modern (at that time) genetic techniques to make his point gave respectability to his work. On the other hand, there is an underlying notion in his work about directionality in evolution which also sets him apart from contemporary neo-Darwinian thinking. As a matter of fact, the notion of 'regressive evolution' is still the central theme among members of the most productive group of hypogean fish researchers at the Zoological Museum and Zoological Institute at the University of Hamburg. This idea of 'regressive evolution' has been the source of monographic texts and, as Thinès (1969) book title, the central idea for describing (although not necessarily explaining) the common features among troglomorphic organisms.

The major problem with 'regressive evolution' is that it gives the impression that the evolution of cave organisms is not the result of Darwinian mechanisms and, thus, set apart from mainstream evolutionary thought as evidenced by the attempts to explain phenotypic simplification by means of neutral mutations (e.g., Wilkens 1988). However, this view of cave life had three difficulties: (1) shared characteristics among troglomorphic organisms that are phylogenetically unrelated seem to be an excellent example of convergent evolution and are therefore easily explained by using neo-Darwinian mechanisms; (2) the fact that the gain and loss of characters in evolution is a common phenomenon; for example, nobody has had the antianthropocentric temerity to label Homo sapiens the result of 'regressive evolution' because that species lost the tail, most of the pelage, and the ability to graciously jump from one tree to another from its ancestors; (3) if this evolution is regressive, then the question of 'regressive to where?' remains unanswered (for further discussion see Romero 1985).

From the neo-Darwinian side, this period begins with the work of Thomas Layman Poulson (1934-) who, in the early 1960 s started to apply new ecological concepts to the study of cave adaptation for amblyopsids, a fish family whose study had largely been neglected since the times of Eigenmann. Poulson took a closer look at some of the adaptations to this environment such as metabolic rate, life history, sensory morphology and foraging behavior, and tried to draw a step-by-step description of that process from a holistic viewpoint by comparing different species within the same family. This approach was in tune with the neo-Darwinian view of evolution in which adaptationism and gradualism play a major descriptive role (Poulson 1963, 1964). However, he would later take a view that combined both neutralism and selectionism when trying to explain the evolution of troglomorphic features (Poulson 1985). He viewed neutralism and selection as complementary and not mutually exclusive for traits that show evolutionary reduction. His approach was strongly comparative where different species of amblyopsids, with different relative evolutionary time in caves, constitute natural experiments.

Another influential American biospeleologist of this period is David Clair Culver (1944-). Although he worked on cave crustaceans and not on cave fishes, his ideas were, and continue to be, influential in the field. He also took a look at the phenomenon of troglomorphy from an ecological viewpoint and applied island biogeography theory to a system that, ecologically speaking, was largely isolated (Culver 1976). Although he initially took a neutralist stance (Culver \& Fong 1986), his more recent studies convinced him that selection does play a major role in the convergence of troglomorphic features (e.g., Culver et al. 1995).

One of the most influential papers during that, this time of philosophical conflict, did not come from hypogean fish specialists but rather from people trying to apply molecular techniques to the understanding of genetic variation. That was the case in the study of evolutionary genetics of the cave Astyanax fasciatus (Avise \& Selander 1972). Largely based on the Master's thesis by John Charles Avise (1948-) directed by his adviser Robert Keith Selander (1927-), this work demonstrated that highly divergent morphologies (epigean vs. troglomorphic) can be achieved with very little genetic differentiation. This, in turn, questioned the validity of the typological thinking of assigning new species, and specially new generic status, to any troglomorphic population based only on blindness and depigmentation.

This new genetic information signaled the possibility that major phenotypic modifications could be achieved by relatively minor genetic changes, as long as those changes affected developmental genes. This notion has been supported by recent studies and is invigorating the study of cave fishes as models in developmental evolutionary biology (e.g., Yamamoto \& Jeffery 2000). 


\section{Conclusions}

The history of hypogean fish research has been marked by rather precise intellectual contexts. Each of the periods described above has been heavily influenced by particular lines of thoughts that were very popular at that time. It seems that most researchers have used hypogean fishes as examples to justify their own philosophical stances rather than to use these subjects for the sake of scientific discovery. The use of these fishes, first to support a neo-Lamarckian view of evolution, then to practice a typological view of classification, and third to demonstrate that they must represent some sort of stage in alleged evolutionary trends, have marred what may have been an excellent topic for more mainstream evolutionary studies. This latter view has, probably, been the most perversive of all given the jargon used by most researchers ('regressive', 'degenerative', etc.) to describe their evolutionary history.

But we should not blame them for that. After all, the idea of progress has been the backdrop to evolutionary thinking and not until recently have we started to realize that the notion of evolutionary progress is a fallacy (Maynard Smith \& Szathmary 1995, 1999). In my view, it is a cultural construct that fits perfectly with anthropocentric ideas that have dominated human notions of ourselves since the dawn of history. This is an idea that has been central in the battles science has fought to enlighten humankind, from geocentrism to creationism. The idea that, somehow, humans represent the zenith of evolution and that anything else is inferior - anything not aiming there is regressive or degenerative.

However, if we see troglomorphic fauna in general and troglomorphic fish in particular, from a less philosophically charged perspective, we will find that they are part of nature and that the characters that amaze us, mostly their blindness and depigmentation, are part of common biological phenomena found everywhere in nature, such as loss of eyes and pigmentation among deep-sea fishes, loss of wings among birds and insects living on islands and caves, or loss of limbs among cetaceans. Further, that the loss of certain phenotypic characters can take place thanks to relatively minor genetic re-arrangements.

Also, the increasing interest on non-troglomorphic hypogean fishes should shed much light on our understanding of evolution as a dynamic, non-stopping process. The finding of genetically undistinguishable epigean and hypogean populations as well as hypogean species that seem to be in 'status nascendi' is also important (e.g., Borowsky \& Mertz 2001, Burr et al. 2001). It tells us that the separation between both epigean and troglomorphic populations is in many cases very tenuous. To apply typological thinking by creating artificial divides to create species just for the sake of it will mask the reality of the fluidity in nature, that nothing stands stills as originally understood by Heraclitus (ca. 540-ca. 480 B.C.) (Wheelwright 1959, p. 29).

When we see troglomorphic fishes we should see them as life trying to occupy every possible space; after all, evolution is opportunistic (Dobzhansky 1970). This is a view more in tune with the Red Queen Hypothesis (Van Valen 1973), according to which organisms will keep changing their phenotype while attempting to survive both as individuals and/or through their genes. Troglomorphic fishes, by evolving from their epigean ancestors, are just trying to make the best of an environment lacking visual information.

And that brings us to the last point. One of the reasons why the notion of evolution by means of natural selection has taken so long to be accepted, and is still debated today, is because of misunderstandings at different levels of how natural selection works. Students of the hypogean fauna have historically missed the point that it is precisely this fauna that represents one of the prime examples of convergent evolution. This is understandable given that the study of convergence and the constraints of form have never been the subject of a single synthesis (Conway Morris 1998). The study of hypogean fishes has the potential to help us better understand how convergence works.

\section{Acknowledgements}

Andrew Miller helped to compiled the bibliography in the data base. Jerry Reedy of Macalester College revised my translation of Kircher's passages on cave fishes. Herman W. de Swart secured the Dutch translation of Kircher's Mundus Subterraneus at the library of the National Museum for the History of Science in Boerhaave, Leiden, and sent translations of some its portions. Janis Langins of the University of Toronto provided a copy of Montalembert's portrait. The following people provided me with information or hints where to find information about Theodore Tellkampf: Toby A. Appel of Yale University, Frederick B. Churchill of 
Indiana University, Uwe Kunert (a Tellkampf relative) from Germany, Edward T. Morman of the New York Academy of Medicine, Lynn K. Nyhart of the University of Wisconsin-Madison, Jocelyn K. Wilk of the Columbia University Archives \& Columbiana Library, Mary P. Winsor of the University of Torornto and Robert Young of the Museum of Comparative Zoology at Harvard University. William G. Saul of the Academy of Natural Sciences provided useful information on the specimens originally classified as 'Gronias nigrilabris' that are deposited at the Academy's collection. Mark Sabaj of Department of Ichthyology of The Academy of Natural Sciences of Philadelphia provided information about the specimens of $A$. spelaea at that institution. G. Teugels, of the Musée Royal del'Afrique Centrale, in Tervuren, Belgium, provided useful information on Georges Boulenger. Steven Johnson Librarian and archivist of the Wildlife Conservation Society provided useful information on Myron Gordon. James W. Atz read the section on C.M. Breder and made valuable suggestions. Olga Mayayo did the drawing of 'Gronias nigrilabris'. Jessica Romero secured a copy of the entire collection of the Memoirs of the Wernerian Society in search of an alleged first printed reference to a Kentucky 'eyeless' fish. Lisa Palmer of the Smithsonian Institution, Carolyn Rainey of the Scripps Institution of Oceanography, Mary Messing of the Wildlife Conservation Society, and Dana A. Fisher provided some of the illustrations and permission to use them for this article. Thomas Poulson and David Culver read the portions where their work was described and contributed with suggestions. Jakob Parzefal read the section on Curt Kosswig and also provided useful information. Karen Lucatelli and Kelly M. Paulson read the entire manuscript and made valuable suggestions.

\section{References cited}

Agassiz, E. (ed.). 1885. Louis Agassiz: his life and correspondence, Vol. 1. Macmillan and Company, London. 794 pp.

Agassiz, L. 1847 [1848]. [Plan for an investigation of the embryology, anatomy and effect of light on the blind-fish of the Mammoth Cave; Amblyopsis spelaeus]. Proc. Amer. Acad. Arts Sci. 1: 1-180.

Agassiz, L. 1851. Observations on the blind fish of the Mammoth Cave. Amer. J. Sci. 11: 127-128.

Agassiz, L. 1859. An essay on classification. Longman, Brown, Greer, Longmans, Roberts, London. 381 pp.

Alvarez, J. 1946. Revisión del género Anoptichthys con descripción de una especie nueva (Pisc., Characidae). An. Esc. Nac. Cienc. Biol. Mex. 4: 263-282.
Alvarez, J. 1947. Descripción de Anoptichthys hubbsi caracinido ciego de la cueva de los Sabinos, S.L.P. Rev. Soc. Mex. Hist. Nat. 8: 215-219.

Anonymous. 1842. [Mammoth Cave blind crayfish and fish]. Proc. Acad. Nat. Sci. Phil. 1: 175.

Appel, T.A. 1988. Jeffries Wyman, philosophical anatomy, and the scientific reception of Darwin in America. J. Hist. Biol. 21: $69-94$.

Atz, J.W. 1986. C.M. Breder, Jr. 1897-1983. Copeia 1986: 853-856.

Avise, J.C. \& R.K. Selander. 1972. Evolutionary genetics of cavedwelling fishes of the genus Astyanax. Evolution 26: 1-19.

Baird, S.F. 1872. Living eyeless fish. Ann. Rec. Sci. Indust. 1871: 266.

Barr, T.C. 1966. Evolution of cave biology in the United States, 1822-1965. Nat. Speleol. Soc. Bull. 28: 15-21.

Bateson, W. 1922. Evolutionary faith and modem doubts. Science 55: 1412.

Beddall, B.G. 1983. The isolated Spanish genius - myth or reality? Félix de Azara and the birds of Paraguay. J. Hist. Biol. 16: 225-258.

Besson, J. 1569 [1969]. L'art et science de trouver les eaux et fontaines cachees soubs terre: autrement que par les moyens vulgaires des agriculteurs et architectes. E. Gibier, Orléans. 83 pp. [facsimile reproduction by Editions Coral, Columbus].

Blanc, M., J.-L. Gaudet, P. Bănărescu \& J.-C. Hureau. 1971. European inland fish: a multilingual catalogue. Fishing News (Books) Ltd., London. 149 pp.

Bocking, S. 1988. Alpheus Spring Packard and cave fauna in the evolution debate. J. Hist. Biol. 21: 425-456.

Borowsky, R.B. \& L. Mertz. 2001. Genetic differentiation among populations of the cave fish Schistura oedipus (Cypriniformes: Balitoridae). Env. Biol. Fish. 62: 225-231 (this volume).

Boulenger, G. 1893. Blind animals in caves. Nature 47: 608 .

Boulenger, G. 1922. Description d'un poisson aveugle decouvert par M.G. Geerts dans la grotte de Thysville (Bas-Congo). Rev. Zool. Afr. 9: 252-253.

Bowler, P.J. 1984. Evolution. The history of an idea. University of California Press, Berkeley. 412 pp.

Breder, C. M. 1942. Descriptive ecology of La Cueva Chica, with especial reference to the blind fish, Anoptichthys. Zoologica 27: 7-15.

Bridges, W. 1954. Zoo expeditions. Curator Publications, New York. $191 \mathrm{pp}$.

Brooks, W.K. 1909. Biographical memoir of Alpheus Hyatt (1838-1902). Biogr. Mem. Nat. Acad. Sci. USA 6: 311-325.

Burgess, W.E. 1989. An atlas of freshwater and marine catfishes: a preliminary survey of the Siluriformes. T.F.H. Publications, Neptune City. 784 pp.

Burr, B.M., G.L. Adams, J.K. Krejca, R.J. Paul \& M.L. Warren, Jr. 2001. Troglomorphic sculpins of the Cottus carolinae species group in Perry County, Missouri: distribution, external morphology, and conservation status. Env. Biol. Fish. 62: 279-296 (this volume).

Chen, Y.-R., J.-X. Yang \& Z.-G. Zhu. 1994. A new fish of the genus Sinocyclocheilus from Yunnan with comments on its characteristic adaptation (Cypriniformes: Cyprinidae). Acta Zootax. Sinica 19: 246-253 (in Chinese). 
Cockerell, T.D.A. 1920. Biographical memoir of Alpheus Spring Packard 1839-1905. Biogr. Mem. Nat. Acad. Sci. USA 9: 181-236.

Coe, W.R. 1918. A century of zoology in America. pp. 391-438. In: E.S. Dana (ed.) A Century of Science in America, Yale University Press, New Haven.

Conway Morris, S. 1998. The crucible of creation. The Burgess Shale and the rise of animals. Oxford University Press, Oxford. 242 pp.

Cope, E.D. 1864. On a blind silurid from Pennsylvania. Proc. Acad. Nat. Sci. Phil. 1864: 231-233.

Cope, E.D. 1896. The primary factors of organic evolution. Open Court, Chicago. 547 pp.

Culver, D.C. 1976. The evolution of aquatic cave communities. Amer. Nat. 110: 955-957.

Culver, D.C. \& D.W. Fong. 1986. Why all cave animals look alike. Stygicola 2: 208-216.

Culver, D.C., T.C. Kane \& D.W. Fong. 1995. Adaptation and natural selection in caves. Harvard University Press, Cambridge. 223 pp.

Cuvier, G. 1828 [1995]. Historical portrait of the progress of ichthyology: from its origins to our own time. Johns Hopkins University Press, Baltimore. 366 pp.

Darwin, C. 1859. On the origin of the species by means of natural selection. J. Murray, London. 502 pp.

Darwin, C. 1861. On the origin of the species by means of natural selection. J. Murray, London. 538 pp.

Davidson, R. 1840. An excursion to the Mammoth Cave, and the barrens of Kentucky. With some notices of the early settlement of the state. A.T. Skillman \& Son, Lexington. 148 pp.

Dean, B. 1916-1923. A bibliography of fishes. American Museum of Natural History, New York, Vol. 1, 718 pp., Vol. 2. 702 pp., Vol. 3, 707 pp.

DeKay, J.E. 1842. Zoology of New York or the New-York fauna, Part IV, fishes. W. \& A. White \& J. Visscher, Albany. 566 pp.

Demoor, J., J. Massart \& É. Vandervelde. 1897. L'évolution régressive en biologie et en sociologie. Félix Alacn, Paris. 324 pp.

Dexter, R.W. 1965. The "Salem secession" of Agassiz zoologists. Essex Inst. Hist. Coll. 101: 27-39.

Di Caporiacco, L. 1926. Un nuovo genere di ciprinide somalo delle acque di pozzo (One new cyprinid genus from a well in Somalia). Monit. Zool. Ital. 37: 23--25.

Dobzhansky, T. 1970. Genetics and the evolutionary process. Columbia University Press, New York. 505 pp.

Eigenmann, C.H. 1890. The Point Loma blind fish and its relatives. Zoe 1: 65-96.

Eigenmann, C.H. 1903. In search of blind fishes in Cuba. World Today 5: 1131-1136.

Eigenmann, C.H. 1909. Cave vertebrates of America. A study in degenerative evolution. Carnegie Institution of Washington, Washington, D.C. $241 \mathrm{pp}$.

Eigenmann, C.H. 1919. Trogloglanis pettersoni a new blind fish from San Antonio, Texas. Proc. Amer. Phil. Soc. 58: 397-400.

Flint, J. 1822. Letters from America, containing observations on the climate and agriculture of the western states, the manners of the people, the prospects of emigrants, \& c., \& c. [sic] W. \& C. Tait, Edinburgh. 330 pp.
Gianferrari, L. 1923. Uegitglanis zammaranoi un nuovo siluride cieco africano (Uegitglanis zammaranoi, a new African cave silurid). Soc. Ital. Sci. Nat. Milan. 62: 1-3.

Gifford, G.E. 1967. An American in Paris, 1841-1842: four letters from Jeffries Wyman. J. Hist. Med. Allied Sci. 22: 274-285.

Girard, C.F. 1859. Ichthyological notes. Proc. Acad. Nat. Sci. Phila. 1859: 63-64.

Girard, C.F. 1888. Les poissons souterrains du nouveau monde. Le Naturaliste 10: 222.

Gresser, E.B. \& C.M. Breder. 1940. The histology of the eye of the cave characin, Anoptichthys jordani. Zoologica 25: 113-116.

Goeldi, E.A. 1905. Nova zoologica aus der Amazonas-Region. Compt. Rend. 6th Congr. Inter. Zool. 1905: 542-549.

Guillaume, J.-L. 1971. La marche au socialism. Évolution progressive ou régressive? Centre d'Études Politiques et Civiques, Paris. 52 pp.

Günther, A.C.L.G. 1880. An introduction to the study of fishes. A. and C. Black, Edinburgh. 720 pp.

Gurnee, R. 1992. A brief history of cave studies in the United States before 1887 (16th to the 19th Century). J. Spelean Hist. 26: 11-20.

Horder, T.J. 1998. Why do scientists need to be historians? Q. Rev. Biol. 73: 175-187.

Hubbs, C.L. 1938. Fishes from the caves of Yucatan. Camegie Inst. Wash. Publ. (491): 261-295.

Hubbs, C.L. 1964. History of ichthyology in the United States after 1850. Copeia 1964: 42-60.

Hubbs, C.L. \& W. T. Innes. 1936. The first known blind fish of the family Characidae: a new genus from Mexico. Occ. Pap. Mus. Zool. (342): 1-7.

Innes, W.T. 1937. A cavern characin Anoptichthys jordani, Hubbs and Innes. Aquarium 5: 200-202.

Jackson, J.R. \& W.C. Kimler. 1999. Taxonomy and the personal equation: the historical fates of Charles Girard and Louis Agassiz. J. Hist. Biol. 32: 509-555.

Jordan, D.S. 1905. The history of ichthyology, an address by David Starr Jordan. Proc. Amer. Assoc. Adv. Sci. 51: 427-456.

Kircher, A. 1665. Mundus subterraneus, in XII libros digestus; quo divinum subterrestris mundi opificium, mira ergasteriorum naturæ in eo distributio, verbo pantámorphou Protei regnum, universæ denique naturæ majestas \& divitiæ summa rerum varietate exponuntur, 2 volumes. J. Janssonium \& E. Weyerstraten, Amsterdam. 938 pp.

Kosswig, C. 1949. Phänomene der regressiven Evolution im Lichte des Genetik. Communs. Fac. Sci. Univ. Ankara 2: 110-150.

Kosswig, C. 1960. Darwin und die degenerative evolution. Abhandl. Verh. Naturw. Ver. Hamburg 4: 21-42.

Lankester, E.R. 1880. Degeneration: a chapter in Darwinism. Macmillan, London. 75 pp.

Lankester, E.R. 1893. Blind animals in caves. Nature 47: 389.

Maynard Smith, J. \& E. Szathmáry. 1995. The major transitions in evolution. Oxford University Press, New York. 346 pp.

Maynard Smith, J. \& E. Szathmáry. 1999. The origins of life. Oxford University Press, Oxford. 180 pp.

Miranda-Ribeiro, A. 1907. Una novedade ichthyologica. Kosmos 4: 21-22. 
Mitchell, R.W., W.H. Russel \& W.R. Elliot. 1977. Mexican eyeless characin fishes, genus Astyanax: environment, distribution, and evolution. Special Publications No. 12, Texas University Press, Lubbock. 89 pp.

Montalembert, M.-R. 1748. Observations de physique générale. Hist. Acad. Roy. Sci. 1748: 27-28.

Motas, C. 1962. Emil G. Racovitza: founder of biospeleology. Nat. Speleol. Soc. Bull. 24: 3-8.

Myers, G.S. 1964. A brief sketch of the history of ichthyology in America to the year 1850. Copeia 1964: 33-41.

Nisbet, R. 1979. History of the idea of progress. Basic Books, Inc., New York. 370 pp.

Norman, J.R. 1926. A new blind catfish from Trinidad, with a list of the blind cave-fishes. Ann. Mag. Nat. Hist. 18: 324-331.

Packard, A. 1871. The Mammoth Cave and its inhabitants. Amer. Nat. 5: 739-761.

Packard, A. 1888. The cave fauna of North America with remarks on the anatomy of the brain and origin of the blind species. Mem. Nat. Acad. Sci. 4: 1-156.

Packard, A. 1901. Lamarck, the founder of evolution, his life and work. Longmans, Green, and Co., New York. 451 pp.

Petit, G. 1933. Un poisson cavernicole aveugle des eaux douces de Madagascar. Compt. Rend. Hebd. Séanc. Acad. Scienc. 4: 347-348.

Pietsch, T.W. \& W.D. Anderson, Jr. (ed.) 1997. Collection building in ichthyology and herpetology. American Society of Ichthyologists and Herpetologists, Lawrence. 593 pp.

Poey, F. 1858. Memorias sobre la historia natural de la isla de Cuba, 2 volumes. Barcina, Habana. 439 pp.

Poly, W.J. 2001. Nontroglobitic fishes in Bruffey-Hills Creek Cave, West Virginia, and other caves worldwide. Env. Biol. Fish. 62: 73-83 (this volume).

Poulson, T.L. 1963. Cave adaptation in amblyopsid fishes. Amer. Midl. Nat. 70: 257-290.

Poulson, T.L. 1964. Animals in aquatic environments: animals in caves. pp. 749-771. In: D.B. Dill, E.F. Adolph \& C.G. Wilber (ed.) Handbook of Physiology, Section 4: Adaptation to the Environment, American Physiological Society, Washington, D.C.

Poulson, T.L. 1985. Evolutionary reduction by neutral mutations: plausibility arguments and data from amblyopsid fishes and linyphiid spiders. Nat. Speleol. Soc. Bull. 47: 109-117.

Putnam, F.W. 1872. The blind fishes of the Mammoth Cave and their allies. Amer. Nat. 6: 6-30.

Putnam, F.W. 1874. [The blind fish and some of the associated species of the Mammoth Cave, Kentucky, probably of marine origin]. Bull Essex Inst. 6: 191-200.

Regan, C.T. 1940. The fishes of the Gobiid genus Luciogobius Gill. Ann. Mag. Nat. Hist. 5: 462-465.

Romero, A. 1984. Charles Marcus Breder, Jr. 1897-1983. Nat. Speleol. Soc. News 42: 8.

Romero, A. 1985. Can evolution regress? Nat. Speleol. Soc. Bull. 47: 86-88.

Romero, A. 1986a. Charles Breder and the Mexican blind characid. Nat. Speleol. Soc. News 44: 16-18.

Romero, A. 1986b. He wanted to know them all: Eigenmann and his blind vertebrates. Nat. Speleol. Soc. News 44: 379-381.

Romero, A. 1999a. The blind cave fish that never was. Nat. Speleol. Soc. News 57: 180-181.
Romero, A. 1999b. Myth and reality of the alleged blind cave fish from Pennsylvania. J. Spelean Hist. 33: 67-75.

Romero, A. 2000 . The speleologist who wrote too much. Nat. Speleol. Soc. News 58: 4-5.

Romero, A: 2001a. It's a wonderful hypogean life: a guide to the troglomorphic fishes of the world. Env. Biol. Fish. 62: 13-41 (this volume).

Romero, A. 2001b. The life and work of a little known biospeleologist: Theodore Tellkampf. J. Spelean Hist. (in press).

Romero, A. \& K. Benz. 2000. The unsung heroes of speleology. Nat. Speleol. Soc. News 58: 106, 126.

Romero, A. \& J.E. Creswell. 2000. In search of the elusive "eyeless"cave fish Trinidad, W.I. Nat. Speleol. Soc. News 58: 282-283.

Romero, A. \& Z. Lomax. 2000. Jacques Besson, cave eels, and other alleged European cave fishes. J. Spelean History (in press).

Romero, A. \& K.M. Paulson. 2001. Humboldt's alleged cave fish from Ecuador. J. Spelean Hist. (in press).

Romero, A. \& A. Romero. 1999. On Cope, caves, and skeletons in the closet. Nat. Speleol. Soc. News 57: 341-343.

Ruse, M. 1996. Monad to man. The concept of progress in evolutionary biology. Harvard University Press, Cambridge. 629 pp.

Shaw, T.R. 1992. History of cave science. The exploration and study of limestone caves, to 1900 . Sydney Speleological Society, Broadway. $338 \mathrm{pp}$.

Smallwood, W.M. 1941. Natural history and the American mind. Columbia University Press, New York. 445 pp.

Soule, G.K. 1982. A Mammoth cave chronology. J. Spelean Hist. 16: 3-9.

Tellkampf, T. 1844a. Beschreibung einiger neuer in der Mammuth-Höhle in Kentucky aufgefundener Gattungen von Gliederthieren. Arch. Vereins Freund Natur. Mecklenburg 10: 318-322.

Tellkampf, T. 1844b. Über den blinden Fisch der Mammuthhöhle in Kentucky. Muller's Arch. Anat. Phys. 1844: 381-395.

Tellkampf, T. 1870. Note respecting the eyes of Amblyopsis spelaeus. Ann. Lyc. Nat. Hist. N.Y. 9: 150-152

Thinès, G. 1969. L'evolution regressive des poissons cavernicoles et abyssaux. Masson et Cie, Paris. 394 pp.

Thompson, W. 1844. Notice of the blind fish, cray-fish, and insects from the Mammoth Cave, Kentucky. Ann. Mag. Nat. Hist. 13: 111-113.

Trewavas, E. 1936. Dr. Karl Jordan's expedition to South-West Africa and Angola. The fresh water fishes. Novit. Zool. 40: 63-76.

Van Valen, L. 1973. A new evolutionary law. Evol. Theor. 1: 1-30.

Vandel, A. 1965. Biospeleology. The biology of cavernicolous animals. Pergamon Press, Oxford. 524 pp.

Vinciguerra, D. 1924. Descrizione di un ciprinide cieco proveniente dalla Somalia Italiana (Description of a blind cyprinid from the Italian Somalia). Ann. Mus. Civ. Stor. Nat. Genoa 51: 239-243.

von Baer, K.E. 1828. Über Entwickelungsgeschichte der Thiere. Beobachtung und Reflexion. Bei Ben Gebtdern Borntrager, Königsburg. 315 pp.

von Humboldt, A. 1805. Quatrième mémoire, sur une nouvelle espèce de pimelode, jetée par les volcans du royaume de Quito. pp. 40-48. In: Voyage de Humboldt et Bonpland, Deuxième 
partie, Observations de Zoologie et d'Anatomie comparée, F. Schoell, Paris.

Wheelwright, P. 1959. Heraclitus. Princeton University Press, Princeton. $181 \mathrm{pp}$.

Wilkens, H. 1988. Evolution and genetics of epigean and cave Astyanax fasciatus (Characidae, Pisces). Support for the neutral mutation theory. Evol. Biol. 23: 271-367.

Wyman, J. 1843. Description of a 'Blind Fish,' from a cave in Kentucky. Amer. J. Sci. 45: 94-96.

Wyman, J. 1851. [Account of dissections of the blind fishes (Amblyopsis spelaeus) from the Mammoth Cave, Kentucky]. Proc. Boston Soc. Nat. Hist. 3: 349, 375.
Wyman, J. 1854a. The eyes and organs of hearing in Amblyopsis spelaeus. Proc. Boston Soc. Nat. Hist. 4: 149-151.

Wyman, J. 1854b. On the eye and the organ of hearing in the blind fishes (Amblyopsis spelaeus DeKay) of the Mammoth Cave. Proc. Boston Soc. Nat. Hist. 4: 395-396.

Wyman, J. 1872. Notes and drawings of the rudimentary eye, brain, and tactile organs of Amblyopsis spelaeus. Amer. Nat. 6: 16-20.

Yamamoto, Y. \& W.R. Jeffery. 2000. Central role for the lens in cave fish eye degeneration. Science 289: 631-633. 